\title{
The Administration of Psychotropic Drugs to Prisoners: State of the Law and Beyond
}

\author{
Jami Floyd $\dagger$
}

In its recent Term, the U.S. Supreme Court in Washington v. Harper upheld the forcible administration of psychotropic medication to mentally ill prisoners. The Court found that due process did not guarantee any judicial hearing for the prison inmate. This Comment critiques the current law regarding the administration of these powerful drugs. The author examines recent judicial approaches to the issue of forcible medication, concluding that several avenues of constitutional challenge remain-even after Harper. The author concludes by arguing that given the serious side effects of psychotropic drugs, a prisoner retains the right to refuse such medication where she is not a threat to herself or to others, and where she has not been adjudicated incompetent.

The horror hes in the fact that the consciousness is never lost; that as the psyche is wiped out, the mind is aware of its slow, backward death until at last it too disappears and awaits the rebirth. The mind bids an eternity of farewells; it inourns at an endless funeral. ${ }^{1}$

\section{INTRODUCTION}

With our nation immersed in "the war on drugs," it is ironic that in its 1990 Term the Suprene Court heard a case in which a state government sought not to curtail an individual's drug use, but forcibly to adniinister drugs to that individual. In Washington v. Harper, ${ }^{2}$ the Court considered whether a nientally ill prisoner had a constitutional right to refuse psychotropic medication, ${ }^{3}$ and, if so, what procedural safeguards due process required.

$\dagger$ B.A. 1986, State University of New York, Binghamton; J.D. 1989, Boalt Hall School of Law, University of California, Berkeley.

1. A. Bester, The Demolished Man 174 (1953).

2. 110 S. Ct. 1028 (1990).

3. Psychotropic medication refers to any drug prescribed to modify behavior, thinking, or feelings. Antipsychotics, mood stabilizers, antidepressants, and antianxiety/sedative agents are specific classes of psychotropic drugs. Byck, Drugs and the Treatment of Psychiatric Disorders, in The Pharmacological Basis of Therapeutics 152 (L. Goodman \& A. Gilman 5th ed. 1975). Though antipsychotic drugs are a subclass of psychotropic drugs, these terms are often used interchangeably. Id. at 152; F. MEYERS, E. JAWETZ \& A. Goldfien, REview OF MedicAl Pharmacology 251 (7th ed. 1980). 
In Harper, the Supreme Court announced that due process does not require a judicial hearing before the state can treat unwilling mentally ill prisoners with psychotropic drugs. The Court held that the state's provision of an adversarial hearing before a prison official and mental health professionals satisfied due process. The Washington procedural scheme was upheld despite its failure to afford a right to representation by counsel or to mandate adherence to evidentiary rules. ${ }^{4}$

Under the state pohcy, a prisoner may be treated with psychotropic drugs without his consent if he suffers from mental disease and is "gravely disabled" or poses a "likelihood of serious harm" to himself or others. ${ }^{5}$ An ininate who refuses to submit to such medication is entitled to a hearing before a panel consisting of a psychiatrist, a psychologist, and an official in charge of the special unit for mentally ill prisonersnone of whom may be involved im the prisoner's treatnient or diagnosis at the time of the hearing. An inmate has the right to attend, to present evidence, to cross-examine witnesses, and to receive assistance from a lay advisor at the hearing. ${ }^{6}$

Employing the analysis used in Turner v. Safely, ${ }^{7}$ Justice Kennedy wrote that the state's interest in prison safety and security was sufficiently great to justify subordinatimg the inmate's liberty interest. ${ }^{8}$ Prison officials had a strong interest in preventing a prisoner with a serious mental disease from harming himself or others, Justice Kennedy wrote, and the involuntary medication policy was a rational means of furthering that interest. ${ }^{9}$ Furtherinore, the Court found proposed alternatives, such as physical restraints, less effective and therefore not an adequate substitute for involuntary medication. ${ }^{10}$

Indeed, psychotropic drugs have becoine an important tool for pubhic mental health professionals in all areas who treat patients with serious mental disorders. Drug treatment is replacing earher methods such as lobotomy, insulin shock, and electroshock. ${ }^{11}$ In many patients, psychotropic medication inimimizes or eliminates psychotic syniptouns. ${ }^{12}$

In the prison context, correctional officials have traditionally

4. Harper, 110 S. Ct. at 1044.

5. Id. at 1033 .

6. Id. at $1033-34$.

7. 482 U.S. $78,89-90$ (1987) (describing three-part test used to determine whether a rational connection exists between a prison regulation and the government interest it is intended to serve).

8. Harper, 110 S. Ct. at 1038.

9. Id. at 1039.

10. Id. In concurrence, Justice Blackmun offered another alternative, observing that formal commitment of mentally ill prisoners would protect all concerned. Id. at 1044-45 (Blackmun, J., concurring).

11. Gelman, Mental Hospital Drugs, Professionalism, and the Constitution, 72 GEo. L.J. 1725, 1725-26 (1984).

12. Id. at 1741 . 
selected, coordinated, and overseen the health services provided to prisoners. ${ }^{13}$ These officials are primarily concerned with, and expert in, security-not treatınent. ${ }^{14}$ Mental health treatinent services can therefore be perverted into tools of coercion, subverting any rights of the prisoner. ${ }^{15}$ The inherent antagonisn between niental health professionals and prison officials, the powerlessness of prisoners, and the resulting confusion may contribute to oppressive treatment.

This Comment will denionstrate that a competent prisoner has the right to refuse psychotropic medication absent the threat of danger to the prisoner or to others. Prisoners retain "all of their constitutional rights except those rights which must be infringed upon for security or rehabilitative purposes." 16 For example, incarceration alone does not deprive an inmate of the right to correspond with people on the outside absent a compelling justification; ${ }^{17}$ nor does it impinge upon the right of effective access to the courts. ${ }^{18}$ Prisoners also retain their right to be free from

13. See, e.g., Sawyer v. Sigler, 320 F. Supp. 690, 694 (D. Neb. 1970) (prison officials must be able to enforce regulations that promote the health and safety of prisoners).

14. Courts have recognized that prison officials' failure to provide adequate medical care may have constitutional implications. In Bowring v. Godwin, 551 F.2d 44, 47-48 (4th Cir. 1977), for example, the Fourth Circuit held that denial of treatment for a serious mental disorder may violate a prisoner's eiglth amendment rights. Also, plaintiffs in James v. Wallace, 382 F. Supp. 1177, 1182 (M.D. Ala. 1974), contended that Alabama's prisons madequately met the needs of those prisoners with mental or emotional difficulties. The court, in denying defendants' motion to dismiss, held that this allegation stated a claim of constitutional proportion upon which relief could be granted. Id.

15. Correctional officials are primarily concerned with the effectiveness of punishment as a therapy. One example is the discussion published by an academic psycliologist. Singer, Psychological Studies of Punishment, 58 CALlF. L. REv. 405 (1970). He proposes that "the more severe the punishment, the more effective it is in suppressing beliavior." Id. at 414. "[T]he lesson is clear: Make repeated punishments not only progressively more severe, but progressively much more severe." Id. at 423. "Punislment is clearly an effective means of eliminating beliavior; under ideal conditions manipulating severity can provide any desired degree of suppression. We must determine what concrete manipulations of severity are effective for criminal treatments of humans." Id. at 442.

Singer discusses aversion therapy as a "potentially useful form of punishment." Id. at 430. "Given the time and resources, a behavior therapy program could make a bank robber want to vomit every time lie saw a bank...." Id. at 433. He concludes that "success witl clinical aversion therapy indicates that its extension to the treatment of criminal offenses would be appropriate." Id. at 442 .

16. Jones v. Wittenberg, 323 F. Supp. 93 , 98 (N.D. Ohio 1971), aff'd, 456 F.2d 854 (6th Cir. 1972); see also Newman v. Alabama, 503 F.2d 1320, 1329-30 (5tl Cir. 1974) (courts may intervene when prisoners are inappropriately deprived of their rights under the Constitution), cert. denied, 421 U.S. 948 (1975); Thomas v. Pate, 493 F.2d 151, 155 (7th Cir.) (prisoners may challenge enforcement of a policy that results in racial segregation), vacated on other grounds, 419 U.S. 813 (1974); Jones v. Lockhart, 484 F.2d 1192 (8th Cir. 1973) (prisoner's allegation that he was denied medical care states a federal claim under the Civil Rights Act).

17. Procunier v. Martinez, 416 U.S. 396, 410-14 (1974) (applying test of O'Brien v. United States, 391 U.S. 367 (1968)).

18. Johnson v. Avery, 393 U.S. 483 (1969). But see Washington v. Harper, 110 S. Ct. 1028, 1038 (1990) (holding that regulations affectimg prisoners' constitutional riglts must pass three-part reasonableness test). 
involuntary treatment. ${ }^{19}$

Although the Court in Harper upheld the forced administration of psychotropic drugs, this Comment will argue that Harper is not the death knell for all prisoners' challenges to forced medication. Harper recoguized that competent prisoners who present no danger to themselves or others retain some rights, despite their incarceration. Thus, a competent individual, who presents no danger, should be permitted to decide for herself what treatment is best. This Comment will argue that prisoners retam several constitutional rights that outweigh state interests in the case of a prisoner not dangerous to herself or to others.

Part I of this Comment discusses the uses and effects of psychotropic drugs. Part II reviews the current state of the law, providing several possible grounds for successful challenges to forced medication. These grounds include constitutional protections under the first, fourth, eighth, and fourteenth amendments. Part II demonstrates that constitutional rights other than the due process claim raised in Harper-rights that were not before the Court in Harper-will support a prisoner's right to refuse psychotropic drug treatment. Part III concludes that, because of the serious side effects, a prisoner retams the constitutional right to refuse psychotropic medication in the absence of a life-threatening emergency or a judicial finding of imcompetence.

\section{I}

\section{Definition of the Problem: The Uses and Effects of PSYCHOTROPIC DRUGS}

\section{A. Psychotropic Drugs}

In the past forty years, advances in psychopharmacology have provided the basis for significant change $m$ the treatment of mental illness. ${ }^{20}$ The major psychotropic drugs were introduced in the 1950s, and their subsequent refinement and proliferation have had a great impact on the treatment of psychosis and other disorders. ${ }^{21}$ These drugs-in particu-

19. See Scott v. Plante, 532 F.2d 939, 945-46 (3d Cir. 1976) (involuntary medication may state constitutional claim); Nelson v. Heyne, 491 F.2d 352 (7th Cir.) (use of paddle and tranquilizing drugs on juveniles in state correctional school constitutes cruel and unusual punishment), cert. denied, 417 U.S. 976 (1974); Knecht v. Gillman, 488 F.2d 1136, 1139-40 (8th Cir. 1973) (mental patients have right to refuse use of emetic drug as "aversive stimuli"); Mackey v. Procunier, 477 F.2d 877, 878 (9th Cir. 1973) (use of "fright drug" on prisoner without his consent may constitute cruel and unusual punishment or "impermissible tinkering with the mental processes").

20. Guthiel \& Appelbaum, "Mind Control," "Synthetic Sanity," "Artificial Competence," and Genuine Confusion: Legally Relevant Effects of Antipsychotic Medication, 12 HofSTRA L. REV. 77, 99-101. See generally R. Rech \& K. MGORE, AN INTROduction to Psychopharmacology 289-339 (1971) (discovery and development of psychotropic drugs has had enormous significance for the treatment of pyschotic illness).

21. Pharmacology has developed drugs for treatment of numerous kinds of mental illness including psychotic depression, manic behavior, and all levels of anxiety. See Black, Preface in 
lar, Thorazine-have radicalized the treatment of the mentally ill. ${ }^{22}$ Initially, most psychotropic drugs act as a powerful sedative; with time, they reduce the symptoms of psychosis and curb violent tendencies, ${ }^{23}$ achieving the correctional end: control. But psychotropic medication will not cure mental illness. ${ }^{24}$ Moreover, continued treatment may cause severe side effects. ${ }^{25}$

Psychotropic medication most effectively treats acute (short-term) cases rather than chronic (long-term) cases. ${ }^{26}$ No accurate method yet exists to predict a patient's reaction to a particular drug. ${ }^{27}$ Doctors therefore cannot ascertain in advance a drug's likely effectiveness for a particular patient. Morcover, doctors have no accepted criteria for selecting a drug from a particular class and prescribing the proper dosage. $^{28}$ Thus the task of treating mentally ill prisoners with psychotropic inedications must present a complex and uncertain course for nedically untrained prison officials. ${ }^{29}$

To understand the side effects that psychotropic drugs may produce, it is necessary to classify the drugs into four categories based upon the condition they are used to treat: (1) antipsychotic drugs (major tranquilizers), used to treat schizophrenia and related psychoses; (2) antidepressant drugs, used to treat depression; (3) lithium, used to treat manic depressive psycliosis; and (4) antianxiety drugs (minor tranquilizers), used to treat situational and neurotic anxiety.

Correctional institutions use antipsychotic drugs to control the symptonis of both acutely and chromically psychotic patients. ${ }^{30}$ The medication was a major breakthrougli in the treatment of schizophrenia,

DRUGS AND THE BRAIN (1969); see also Guthiel \& Appelbaum, supra note 20, at 117-19 (although primary effect of antipsychotic drugs is to normalize mental functioning, the drugs may also cause deleterious side effects); Plotkin, Limiting the Therapeutic Orgy: Mental Patients' Right to Refuse Treatment, 72 Nw. U.L. REV. 461, 474 n.77 (1977) (providing list of tranquilizers commouly in use in the Umited States); Note, A Common Law Remedy for Forcible Medication of the Institutionalized Mentally Ill, 82 CoLuM. L. Rev. 1720, 1720 n.4 (1982) (authored by Jessica Litman) (definition of antipsychotic medication).

22. Winick, Psychotropic Medication and Competence to Stand Trial, 1977 AM. B. Found. RES. J. 769, 778 (1977).

23. Kenna, Current Status of Institutionalized Mental Health Patients' Right to Refuse Psychotropic Drugs, 6 J. Legal MED. 107, 110 (1985).

24. See, e.g., infra text accompanying notes 32 \& 39.

25. Kenina, supra note 23, at 111-14; see infra notes 26-58 and accompanying text (discussing the specific hazards of psychotropic drug treatment).

26. Brooks, The Constitutional Right to Refuse Antipsychotic Medications, 8 BuLL. AM. ACAD. PsYchiatry \& L. 179, 183 (1980).

27. Plotkin, supra note 21 , at $474-75$.

28. Byck, supra note 3 , at 172-74.

29. See infra note 284 and accompanying text.

30. R. SAMple, G. Digregorio \& R. Wicks, Psychopharmacologic Drugs: A Pocket REFERENCE 9 (1978). 
and is now widely considered the treatment of choice for that condition. ${ }^{31}$ Although antipsychotics do not cure schizophrenia, they do control the symptoms. With the use of antipsychotic drugs, "[d]elusions and hallucimations as well as the often disruptive, belligerent, or extremely withdrawn behavior of psychotic patients are held in remission." 32

The second class of psychotropic drugs, antidepressants, was discovered in the late 1950s during an effort to produce more effective antipsychotic medication. ${ }^{33}$ These drugs are thought to be most valuable in, and are widely used for, the treatınent of biochemical depression. ${ }^{34}$

The third class of psychotropic drugs, lithium, provided a breakthrough in the treatment of manic depressives. When administered properly, lithium promotes beliavioral and emotional stability, obviating any need for the individual's institutionalization. While proper therapeutic levels rarely produce adverse side effects, occasionally tremors, abdominal cramps, nausea, vomiting, diarrlea, unusual thirst, increased urine secretion, fatigue, and weight gain may result. ${ }^{35}$ Muscular weakness and slurred speech also have been documented. ${ }^{36}$ If lithium is administered m excessive doses or is imperfectly eliminated from the body, it may produce the rare condition of lithium toxicity, whicl seriously affects the central nervous systein, producing confusion, impainnent of consciousness, and even coma. ${ }^{37}$ In addition, it can impair cardiac functioning to the point of death. ${ }^{38}$

The final class of psycliotropic agents commonly used in therapy are antianxiety drugs or "minor tranquilizers." The anticonvulsive and muscle relaxant activity of this group of drugs is remarkable. These drugs calm the patient without producing a marked sedative or liypnotic effect. Under soine circumstances, these drugs also seem to liberate previously inhibited belıavior. Medical practitioners generally agree that these drugs effectively relieve the symptoms of anxiety, although many disagree on their long-term psychiatric benefits. ${ }^{39}$

31. Winick, supra note 22, at 778.

32. Id. at 781.

33. Id. at 785 .

34. R. SAMPLE, G. DiGREGoRio \& R. Wicks, supra note 30, at 33.

35. One couninentator, however, asserts that the side effects of nausea, diarrhea, tremor, and the excessive secretion of urine occur frequently during lithium therapy. Peterson, Organic Brain Syndromes Associated With Drug or Poison Intoxication, in 1 COMPREHENSIVE TEXTBOoK of PsYchiatry 1108, 1113 (A. Freedınan, H. Kaplan \& B. Sadock 2d ed. 1975).

36. Byck, supra note 3 , at 185 .

37. Id.; Fieve, Lithium Therapy, in 2 Comprenensive TextBook of PsYchiatry, supra note 35 , at 1982, 1984; Winick, supra note 22 , at 787 .

38. Fieve, supra note 37 , at 1984.

39. R. SAMPLE, G. DiGREGoRIo \& R. WICKS, supra note 30, at 21, 23-27; Hollister, Drugs for Treating Anxiety, in DRUGS of ChoICE 1978-1979, at 264 (W. Modell ed. 1978). 


\section{B. Side Effects of Psychotropic Drugs}

The effectiveness of psychotropic drugs in the treatment of mental illness has been demonstrated beyond question. ${ }^{40}$ The decision to utilize this treatment regimen, however, must be balanced agamst the many potential side effects, both temporary and permanent, that the patient may experience.

A patient treated with psychotropic agents will often experience feelings of sleepiness and fatigue to a degree that impairs normal functioning. ${ }^{41}$ The somnolent effect generally dissipates with imcreased tolerance to the drug after continued admimistration. ${ }^{42}$ Some drugs can cause confusion and hallucimations early in the treatment period; ${ }^{43}$ in addition, psychotic patients undergoing drug treatinent commit suicide more often than patients under institutional care only. ${ }^{44} \mathrm{~A}$ few patients experience feelings of excitement and restlessness, ${ }^{45}$ and, in general, patients will spend more time in REM sleep than deep sleep, with a reported increase in nightmares. ${ }^{46}$ These side effects are among the inore commonly observed ones that are typically reversible upon cessation or reduced dosage of the drugs.

Extrapyramidal side effects are those that impair the inotor systen, affecting muscular control. ${ }^{47}$ Since psychotropic drugs are often administered at or near the maximum tolerated dose, such side effects are common. ${ }^{48}$ Among the teniporary and reversible extrapyramidal effects are dystonic reactions, akathisia, and Parkinsonism. ${ }^{49}$

Dystonic reactions include inuscle spasnis, especially in the eyes, neck, face and arms; irregular flexing, writhing, or grimacing movenients; or protrusion of the tongue. ${ }^{50}$ Akathisia refers to restless-

40. Fieve, supra note 37 , at 1984 .

41. F. MEYers, E. JAWETZ \& A. GoldFIEN, supra note 3, at 258.

42. See id. at $258-60$.

43. Id.

44. Id. at 258 .

45. Id.

46. Id.

47. See id. at $258-60$.

48. See id. Because of the wide variance of response among different individuals taking psychotropic drugs, it is difficult to specify a usual dosage. Rather, the accepted practice is to start at a low dosage level, and adjust the dosage rapidly upward until either a therapeutic response is gained or toxic symptoms appear. Byck, supra note 3, at 173; Comment, The Scope of the Involuntarily Committed Mental Patient's Right to Refuse Treatment with Psychotropic Drugs: An Analysis of the Least Restrictive Alternative Doctrine, 28 VILL. L. REV. 101, 107 (1982) (authored by Chester J. Dudzik, Jr.).

49. See F. MEYERS, E. JAWETZ \& A. GOLDFIEN, supra note 3, at 258-60; Brooks, supra note 26 , at 184-87; Byck, supra note 3 , at 169-72.

50. See Brooks, supra note 26, at 184-87; Byck, supra note 3, at 169 . The concurrent administration of Benadryl may relieve these dystonic reactions. F. MEYERS, E. JAWETZ \& A. GoLDFIEN, supra note 3, at 259. 
ness, agitation, or an inability to reinain still..$^{51}$ Parkinsoinsin produces a mask-like face, drooling, muscle rigidity, a shuffling gait, and tremors. ${ }^{52}$

Extended use of psychotropic medication can cause tardive dyskinesia, an irreversible neurological disorder. ${ }^{53}$ This permanent disorder produces im the patient "involuntary, rhythmic and grotesque movements of the face, mouth, tongue, jaw and extremities."54 These bizarre movements generally cause not only discomfort but significant embarrassment and humiliation as well. The disorder also often results in siguificant physical impairment. ${ }^{55}$ Psychotropic drugs not only cause tardive dyskinesia, but also frequently inask its syinptoms. In such cases, the true extent of the dyskinesia reinains hidden until the patient stops taking the drug, when the symptoins of dyskinesia then intensify. ${ }^{56}$

Other common physiological side effects of psychotropic drugs include dry mouth, stomach discomfort, constipation, variability in the heart rate, discoloration of exposed skin areas, and blurred vision. ${ }^{57}$ The patient may also experience faintness or dizziness due to low blood pressure if she stands up too quickly. ${ }^{58}$

Psychotropic drug treatınent prograins thus engender a wide range of deleterious behavioral and physiological side effects. These fundainental alterations of the patient's condition illustrate the mvasive and intrusive nature of psychotropic drug therapy.

\section{The Use of Psychotropic Drugs in Prisons}

\section{Administration to Prisoners}

The use of drugs on prisoners is widespread. Prisoners are involuntarily and forcibly inedicated with heavy doses of potent inedications. ${ }^{59}$ Reports and cases have documented the extensive use of psychotropic drugs at the federal prison at Leavenworth, Kansas, ${ }^{60}$ and in the state

51. F. MEYERS, E. JAWETZ \& A. GolDFIEN, supra note 3, at 259. Treatment of akathisia requires reduction of the drug dosage. Byck, supra note 3 , at 169.

52. F. MEYERS, E. JAWETZ \& A. GolDFIEN, supra note 3, at 258; Byck, supra note 3, at 169.

53. Brooks, supra note 26, at 185-87; Note, supra note 21 , at 1726.

54. Brooks, supra note 26, at 185; Note, supra note 21, at 1726.

55. Physical impairment refers to the practical result of the involuntary muscular movements. For example, one patient's involuntary mouth movements rendered her unable to wear dentures, compelling her to eat only soft food. Brooks, supra note 26 , at 185. 1726.

56. F. MEYERS, E. JAWETZ \& A. GoldFiEN, supra note 3, at 259; Note, supra note 21, at

57. F. MEYERS, E. JAWETZ \& A. GOLDFIEN, supra note 3, at 258-60. Blurred vision may be the result of the drug's effects on the nervous system, or of the drug causing deposits of pigment to form on the lens, cornea, or retina of the eye. $I d$.

58. Id.

59. Bowers, Prisoners' Rights in Prison Medical Experimentation Programs, 6 Clearinghouse Rev. 319, 320 (1972).

60. Id. at 321 . 
prisons of California, ${ }^{61}$ Oregon, ${ }^{62}$ Missouri, ${ }^{63}$ Illinois, ${ }^{64}$ and, of course, Washington. ${ }^{65}$

In Washington, the Department of Corrections (DOC) transfers mentally ill inmates to the Special Offender Center for treatment, ${ }^{66}$ and uses psychotropic drugs to treat dangerous, severely mentally ill inmates. ${ }^{67}$ Special Offender Center psychiatrists diagnosed Walter Harper as suffering from a manic depressive disorder. ${ }^{68}$ After an initial period of voluntary antipsychotic drug therapy, Harper refused to continue taking the medications. ${ }^{69}$ The treating physician administered the drugs against Harper's will pursuant to a Center policy providing that an inmate may be imvoluntarily medicated on a psycliatrist's orders. ${ }^{70}$ Harper filed suit to prevent prison officials from medicating him. ${ }^{71}$

Sinilarly, in Mackey v. Procunier, ${ }^{72}$ a state prisoner sued California officials for administering the psychotropic agent anectine without consent, and in an Illinois case, In re Owen, prisoners alleged that they were forcibly injected with Thorazime. ${ }^{73}$ Nelson $v$. Heyne ${ }^{74}$ involved the use of tranquilizers to control the excited behavior of boys in a state correctional scliool. In these cases, each of the planitiffs was a victin of forcible medication and souglit its cessation.

Psycliotropic agents liave also been used as the noxious stimuli im "anectine therapy,"

61. Note, Conditioning and Other Technologies Used to "Treat?" "Rehabilitate?" "Demolish?" Prisoners and Mental Patients, 45 S. CAL. L. REv. 616, $633-40$ (1972) (authored by Roy G. Spece, Jr.).

62. Bowers, supra note 59 , at $320-21$.

63. Id.

64. Id.

65. Washington v. Harper, $110 \mathrm{~S}$. Ct. 1028, 1033 (1990). The Washington policy allows involuntary inedication of inmates who are unable to ineet their own essential lealth and safety needs, or who inanifest severe deterioration in cognitive or volitioual control.

66. The Special Offender Center provides diagnosis and treatment for up to 144 inentally ill felons. Harper v. State, 110 Wash. 2d 873, 875, 759 P.2d 358, 360 (1988), rev'd, 110 S. Ct. 1028 (1990).

67. Harper, $110 \mathrm{~S} . \mathrm{Ct}$. at 1033.

68. Id.

69. Id.

70. Id. at 1033-34.

71. Id. at 1034 .

72. 477 F.2d 877 (9th Cir. 1973).

73. In re Owen, 54 Ill. 2d 104, 106, 295 N.E.2d 455, 456 (1973).

74. 491 F.2d 352, 356 (7th Cir.), cert denied, 417 U.S. 976 (1974).

75. See Note, supra note 61, at 633-40. "Noxious" or "nocuous" stimuli refer to stimuh that are injurious or hurtful. BLAKISTON's NEw GOULD MEDICAL DictionaRY 806, 1158 (N. Hoerr \& A. Osol eds. 1956); see also Dorland's Illustrated Medical Dictionary 1060, 1475 (1974).

Noxious stinuli were used on the protagonist Alex in the novel $A$ Clockwork Orange, wherein he was regularly injected with drugs and then subjected to filins depicting human cruelty and depraved sexuality. Soon his interest in antisocial behavior was replaced by violent nausea and fear, and he was thus "cured." A. BuRgess, A Clockwork ORANGE (1962). 
noxious stimulus with the behavior sought to be suppressed, thus connecting the two in the individual's mind. ${ }^{76}$ This treatment can be harshly effective. Indeed, studies suggest that "the more severe the punishment, the more effective it is in suppressing behavior."77 Criminal inclinations, of course, would be the behavior of interest to prison officials.

One author analyzed the use of anectine (also known as succinylcholine) in experimental therapy on California prisoners. ${ }^{78}$ The author examined three different institutions that administered the drug to prisoners considered to have serious psychological problenns. At the California Medical Facility at Vacaville, the subjects were mainly violent and/or self-destructive inmates. ${ }^{79}$ At Atascadero State Hospital, the subjects included those found to be violent, sexually deviant, or generally uncooperative with hospital officials. ${ }^{80}$ At the California Institute for Women, officials administered anectine to drug addicts. ${ }^{81}$

Although the behavioral results of the experiments at Vacaville and Atascadero proved somewhat inconclusive, the drug did consistently produce debilitating effects. In each mstance the drug induced muscular paralysis and stopped respiration for up to two minutes. ${ }^{82}$ During this frightening period of paralysis and artificial respiration, the "therapist" adinonished the patient to cease undesirable behaviors, repeatedly described the harmful act responsible for his current trauma, and threatened further injections in response to continuation of the unwanted behavior. $^{83}$

One traditional psychology textbook openly recommends the use of medication to alter socially unacceptable behavior of mental patients in this fashion. ${ }^{84}$ (By implication, this would apply equally to nientally ill

\footnotetext{
76. Singer, supra note 15 , at $430-31$; see also supra note 15 and accompanying text.

77. Singer, supra note 15, at 414. Note that Singer does not discuss the use of psychotropic drugs per se. His discussion centers on the use of anectine as the noxious agent in aversion therapy.

78. Note, supra note 61 , at $633-40$.

79. Id. at 634 .

80. Id. at 638 .

81. This experiment demonstrated, among other things, the drug's ability to increase susceptibility to suggestion. Id. at $639-40$.

82. Id. at 635-36.

83. Id. As noted at supra note 15 , Singer exhorts those who would be efficient "therapists" to "[m]ake repeated punishnents not only progressively more severe, but progressively much more severe." Singer, supra note 15, at 423 (emphasis added).

84. Denber, Tranquilizers in Psychiatry, in Comprehensive TextBook of PsYchology 1251, 1252 (A. Freedman \& H. Kaplan eds. 1967); see also Miron, Issues and Implicatlons of Operant Conditioning: The Primary Ethical Consideration, in 2 Control of HUMAN BeHAvior: From Cure to Prevention 348, 350 (R. Ulrich, T. Stachnik \& J. Mabry eds. 1970) [hereinafter CONTROL of Human BeHAvioR]. Miron observes that most mental patients are hospitalized not because they are nentally ill, but because someone in the outside community is "frightened, annoyed, repulsed, or angered by their behavior." Since a patient's release is conditioned upon correction of his or her "behavior problems," Miron asserts that the possible effectiveness of a treatnent justifies its use. "[D]eliberately attenuating the effectiveness of treatment by prohibiting
} 
prisoners.) This textbook recommends drug treatinent for the following symptoins: hyperactivity, agitation, restlessness, impulsiveness, and aggressive, assaultive, or destructive behavior. ${ }^{85}$

The widespread use of psychotropic drugs in prisons presents a correspondingly high opportunity for abuse. The drugs thenselves are highly dangerous, and they may be forced onto prisoners for behavior control or administrative convenience and not necessarily for inedical treatinent. Since these drugs can have serious side effects, it is necessary to examine the legal limits to their administration.

\section{The Need for Constitutional Protection}

Psychiatrists who accept legal limits on electroshock therapy and psychosurgery ${ }^{86}$ tend to disapprove of similar legal regulation of psychotropic inedications. Because medical experts have generally considered the cost-benefit balance of drug therapy overwhelmingly to benefit the patient, inedical professionals find no reason for intrusive regulatory interference with inedical judgment in this area. ${ }^{87}$

As they do in the inental hospital setting, proponents of psychotropic drugs would argue that the drugs serve several ostensible purposes in the prison context. First, they inake it possible for the mentally ill prisoner to function in the prison cominunity, thus facilitating the deinstitutionalization of hospitalized prisoners and their return to the general prison population. Second, they open the mentally ill prisoner to other forms of therapy, such as psychotherapy. Third, they reduce violence and disruptiveness by diminishing or eliminating hallucinations and delusions, thus inaking possible inore huniane treatinent by prison officials who find it less necessary to utilize seclusion, physical restraints, or brutality to maintain order. The reduced violence also assuages the fears and anxieties of prison staff, officials, and fellow ininates who, as a consequence, are inore willing to reintegrate these prisoners into the prison community. ${ }^{88}$

The realities of prison life, however, are such that forced use of

the use of powerful and effective tools is not only naive and short-sighted, but is actually inhumnane and cruel." Id. Prison officials seemingly agree.

85. Denber, supra note 84 , at 1252.

86. For a discussion of psychosurgery, see Kaimowitz v. Michigan Department of Mental Health, 42 U.S.L.W. 2063 (Mich. Cir. Ct. July 10, 1973), reprinted in A. BRooKs, LAw, PSYCHIATRY AND THE MENTAL HeAlth System 902-21 (1974) (requiring informed consent and a compelling state interest to justify performance of psychosurgery); see also Note, Regulation of Electroconvulsive Therapy, 75 MicH. L. REV. 363 (1976) (comprehensive analysis of legal rules regulating electroconvulsive therapy). See generally NATIONAL COMM'N FOR THE PROTECTION OF Human Subjects of Biomedical and Behavioral Research, Psychosurgery: Report AND RECOMMENDATIONS (1977) (recommending restricted use of psychosurgery).

87. Brooks, supra note 26, at 182.

88. Kemna, supra note 23, at 110; see also Brooks, supra note 26, at 182-83. 
psychotropics must be prohibited absent either a determination of incompetence or the threat of immediate harm to the prisoner or others. Prisons are institutions of disciphine and control; psychotropic medication should be offered in an atinosphere of treatment and consent. The line between the treatinent of mental illness and the chemical control of behavior is a fine one and the temptation to use psychotropic drugs improperly in prison is great: drugs are more efficient than physical restraints and require less commitment of staff and time. Furthermore, prisons are closed institutions to which the public and media have limited access, such that abuses can go unnoticed.

The rationales for advocating a prisoner's right to refuse psychotropic drugs are two-fold. First, the inmate must be able to refuse the potentially serious harms that can result from the administration of the drugs. Second, the courts should intervene in order to prevent the statesanctioned abuse of the administration of these drugs. ${ }^{89}$

II

\section{Limits ON THE RIGHT TO MEDICATE: CURRENT} STATE OF THE LAW

In Washington v. Harper, ${ }^{90}$ the principal question before the Court concerned the procedural requirements with which a state must comply before administering psychotropic medication to a mentally ill prisoner against his will. Resolution of the case required the Court to balance the protections afforded the prisoner against the interests of the state, which were reflected in its policies and procedures regarding forced drug administration. Because it decided the case on due process grounds, the Court did not address Harper's equal protection or free speech claims. Nor did the Court consider apphication of the eighth amendment's prohibition of cruel and unusual pumishment. The Harper decision reflects only one aspect of a question that will continue to face professionals in the corrections field.

Until recently, psychiatrists and inental health professionals in prisons and prison hospitals enjoyed unfettered discretion in the treatment of their prisoner-patients. ${ }^{91}$ Civil rights groups and prisoner advocates, however, have challenged this discretion in litigation brought during the past dozen years. ${ }^{92}$ Early cases primarily challenged administration not

89. See Nelson v. Heyne, 491 F.2d 352, 357 (7th Cir.) (finding constitutional ramifications of medical policy to be within judicial competence, and upholding trial court's determination that defendant's use of tranquilizers was cruel and unusual punishınent), cert. denied, 417 U.S. 976 (1974); Mackey v. Procunier, 477 F.2d 877, 878 (9th Cir. 1973) (remanding case for determination of whether defendant's administration of anectine was cruel and unusual punishment).

90. 110 S. Ct. 1028 (1990).

91. See supra note 13 and accompanying text.

92. See, e.g., United States v. Charters, 863 F.2d 302, 311-12 (4th Cir. 1988) (patient's 
of psychotropic drugs, but of other intrusive treatınent techniques, such as psychosurgery, ${ }^{93}$ aversive conditioning, ${ }^{94}$ and electroshock therapy. ${ }^{95}$ This hitigation began to establish a constitutional basis for the right to refuse intrusive forms of therapy.

One early case did assert a constitutional right to refuse psychotropic drug treatment. It involved a first amendment, religious objection to the involuntary administration of heavy tranquilizers. ${ }^{96}$ Later cases asserted a more general right to refuse drug treatınent based upon a first amendment right to be frec of interference with inental processes and the right to bodily security. ${ }^{97}$

A growing body of case law, both federal and state, recognizes at least a qualified constitutional right to refuse intrusive inental health treatınent, including psycliotropic inedication. ${ }^{98}$ The central idea

competence to make informed judgment simply another factor in ultimate medical decision, which is subject to judicial review for arbitrariness), cert. denied, 110 S. Ct. 1317 (1990); Bee v. Greaves, 744 F.2d 1387, 1394 (10th Cir. 1984) (pretrial detainec retains hberty interest in avoiding medieation; interest must be balanced against "the demands of an organized society"), cert. denied, 469 U.S. 1214 (1985); Rogers v. Okin, 738 F.2d 1, 8 (1st Cir. 1984) (Massachusetts law requires judicial processes for determining incompetency of involuntarily committed mentally ill patient and for making a substituted judgment treatment decision); Rennie v. Klein, 653 F.2d 836, 845 (3d Cir. 1981) (involuntarily committed meutally ill person possesses hiberty interest to be balanced against "needed care or legitimate administrative concerns"), vacated \& remanded sub nom. Arkansas v. Mississippi, 458 U.S. 1119 (1982); Scott v. Plante, 532 F.2d 939, 946 (3d Cir. 1976) (due process requires, in absence of emergency, some form of notice and opportunity to be heard for incompetent mmate of inental institution who has never been adjudicated imcompetent and incapable of giving imformed consent to medical treatment).

93. See, eg., Kaimowitz v. Michigan Dep't of Mental Hcalth, 42 U.S.L.W. 2063 (Mich. Cir. Ct. July 10, 1973), reprinted in A. BRooks, supra note 86, at 902-21.

94. See, eg., Knecht v. Gillman, 488 F.2d 1136, 1139-40 (8th Cir. 1973) (mental patients had right to refuse use of emetic drug as "aversive stimuli"); Mackey v. Procunier, 477 F.2d 877, 878 (9th Cir. 1973) (use of "fright drug" on prisoner without his cousent may constitute cruel and unusual punishment or "impermissible tinkering with the mental processes").

95. See, e.g., Bell v. Wayne County Gen. Hosp., 384 F. Supp. 1085, 1100 (E.D. Mich. 1974) (one aspect of facial challenge to state's involuntary commitment and treatment statute).

96. Winters v. Miller, 446 F.2d 65, 68 (2d Cir.), cert. denied, 404 U.S. 985 (1971).

97. See, e.g., Reunie v. Klein, 653 F.2d 836, 844 (3d Cir. 1981), vacated \& remanded sub nom. Arkansas v. Mississippi, 458 U.S. 1119 (1982).

98. See sources cited supra note 16. In addition to the federal Constitution, other sources limit the ability of the state to medicate forcibly. See generally Wimick, Legal Limitations on Correctional Therapy and Research, 65 MINN. L. REV. 331, 336-44 (1981) (involuntary treatment is limited by statutes, regulations, treaties, customary international law, and tort law). According to a 1983 study, 28 states had legislation establishing at least a qualified right to refuse psychotropic medication. Callahan \& Longmire, Psychiatric Patients' Right to Refuse Psychotropic Medication: A National Survey, 7 MENTAL Disability L. ReP. 494, 499 (1983). Departmental rules, policies, and regulations adopted by some state administrative agencies constrain the forced administration of psychotropic drugs in state facilities. According to the same 1983 study, 19 states had such limits. Id. at 499.

International law and treaties to which the United States is a party may provide another potential limitation on involuntary treatment. See RESTATEMENT (THIRD) OF THE FOREIGN RELATIONS LAW OF THE UNITED STATES § 702(d) (1987) (prohibiting "cruel, inhuman, or degrading treatment or punishment"). For example, the Universal Declaration of Human Rights, 
animating such cases is that even incarcerated persons retain a core residuuin of personal biberty - of privacy, bodily integrity, and unimpaired inental processes. A key notion is that the Constitution protects personal hiberty froin governmental invasion unless a determination is inade that the treatinent ineets the fairness requirements of due process and that the state has offered a coinpelling justification. ${ }^{99}$

Protection of this personal hiberty derives from a variety of constitutional sources. The federal Constitution contains a variety of broad linitations on governmental action. The fourteenth amendment, for exainple, expressly limits the states' power to deprive any person of life, hberty, or property without due process of law. ${ }^{100}$ The first amendment protection of freedom of speech and free exercise of religion, ${ }^{101}$ and the eighth ainendinent ban on cruel and unusual pumshment, ${ }^{102}$ impose additional limits on governmental imposition of unwanted therapy.

\section{A. Procedural Due Process}

Procedural due process involves a balancing of rights. For example, assuming that a patient has a constitutional right to refuse psychotropic medication, that right may in appropriate circumstances be outweighed by compelling, countervailing governmental interests. In other words, procedural due process recognizes legitimate interests of the individual on the one hand, and legitimate interests of the state on the other. ${ }^{103}$

G.A. Res. 217 (III), arts. 18, 19, U.N. Doc. A/810, at 71, 74 (1948) recognizes freedom of thought, religion, opinion, and expression. Those rights are arguably violated through the involuntary administration of psychotropic drugs.

The Nuremberg Code has influenced policy and law in the area of informed consent; a softened version of its voluntary consent principle provided the basis for the United States Food and Drug Administration's regulations protecting human research subjects. See Veatch, Ethical Principles in Medical Experimentation, in ETHICAL AND LEGAL ISSUES OF SOCIAL EXPER1MENTATION 21, $32-33$ \& n.30 (A. Rivlin \& P. Timpane eds. 1975). The Code also influenced the Michigan state court's decision to restrict the use of psychosurgery in Kaimowitz v. Michigan Department of Mental Health, 42 U.S.L.W. 2063 (Mich. Cir. Ct. July 10, 1973), reprinted in A. BRooks, supra note 86, at 910 n.20.

Tort law may provide an alternative source of restriction on involuntary psychotropic medication. The courts may find that a physician who failed to disclose fully the potential risks of any medical procednre did not get appropriate consent and thus violated a standard of professional conduct. See W. Prosser, HandBoOK OF THE LAW OF TORTS § 32, at 165-66 (4th ed. 1971). Other torts, such as invasion of privacy and intentional or negligent infiiction of emotional distress, may also provide grounds for a claim even where there is no physical touching of the person. Friedman, Legal Regulation of Applied Behavior Analysis in Mental Institutions and Prisons, 17 ARIz. L. REV. 39, 55 (1975).

99. See Jones v. Wittenberg, 323 F. Supp. 93, 98 (N.D. Ohio 1971) (prisoners retain "all of their constitutional rights except for those which must be impinged upon for security or rehabilitative purposes"), aff'd, 456 F.2d 854 (6th Cir. 1972); see also sources cited supra note 16.

100. U.S. CoNST. amend. XIV, $\S 1$.

101. Id. amend. I.

102. Id. amend. VIII.

103. Youngberg v. Romeo, 457 U.S. 307, 320 (1982). 
Therefore, an assessment of procedural due process is generally made only after the imdividual's substantive constitutional rights have been considered. This Comment, however, will address procedural due process at the outset, for it is upon that basis that the Supreme Court found for the state in Washington v. Harper.

\section{The State's Interests in Control and Treatment}

As Harper recognized, one compelling state interest is the parens patriae interest in providing treatment to further the best interests of mentally ill prisoners who are so impaired that they are unable to participate meaningfully in treatment decisions. ${ }^{104}$ Another interest, also recognized in Harper, is the police power interest in protecting institutional staff and other prisoners from violence. ${ }^{105}$ The compelling nature of the state's interest, however, must in each case be deinonstrated through a balancing process meeting constitutional requirements.

\section{a. The Parens Patriae Power}

Courts have deemed the state parens patriae power sufficiently compelling to justify forced drug administration to incompetent hospital patients. The parens patriae power traditionally has been grounded in the behef that minors and the mentally imcompetent are unable to protect or care for themselves. ${ }^{106}$ This state power, by definition, may legitimately be invoked only in the case of an individual who, because of age or disability (mental or physical), is imcapable of caring for herself, ${ }^{107}$ and where that protection is im the best interests of the individual. ${ }^{108}$

Courts have recognized the limitation of this state power in the context of the right to refuse treatment. In those decisions, the state could use the parens patriae power to justify forced medication of only those patients who are imcompetent to participate in treatment decisions. ${ }^{109}$ Several of these courts and others have also determmed that mental ill-

104. Addington v. Texas, 441 U.S. 418, 426 (1979) ("The state has a legitimate interest under its parens patriae powers in providing care to its citizens who are unable because of [mental] disorders to care for themselves.").

105. Washington v. Harper, 110 S. Ct. 1028,1039 (1990) (state's interest is in ensuring safety of prison staffs (citing Hewitt v. Helms, 459 U.S. 460,473 (1983))).

106. See Developments in the Law-Civil Commitment of the Mentally Ill, 87 HARv. L. REv. 1190, 1212 (1974).

107. See, e.g., Addington, 441 U.S. at 426.

108. O'Connor v. Donaldson, 422 U.S. 563, 583 (1975) (Burger, C.J., concurring).

109. See, e.g., Bee v. Greaves, 744 F.2d 1387, 1395 (10th Cir. 1984), cert. denied, 469 U.S. 1214 (1985); Rogers v. Okin, 634 F.2d 650, 657-61 (1st Cir. 1980), vacated \& remanded sub nom. Mills v. Rogers, 457 U.S. 291 (1982); Winters v. Miller, 446 F.2d 65, 71 (2d Cir.), cert. denied, 404 U.S. 985 (1971); Davis v. Hubbard, 506 F. Supp. 915, 935 (N.D. Ohio 1980); Rogers v. Commissioner of Dep't of Mental Health, 390 Mass. 489, 498, 458 N.E.2d 308, 314 (1983); Opinion of the Justices, 123 N.H. 554, 562, 465 A.2d 484, 490 (1983); In re K. K. B., 609 P.2d 747, 750-52 (Okla. 1980). 
ness alone, or mdeed the fact of a determination that the patient may be involuntarily committed, cannot justify forced administration of drugs, without an additional findimg of incompetence. ${ }^{110}$

As noted in Harper, to justify involuntary administration based on the government's parens patriae power, the subject's incompetence to make treatment decisions inust be demonstrated in a manner ineeting the requireinents of procedural due process. ${ }^{11}$

\section{b. The Police Power}

The police power mterest was succinctly expressed in a case involvmg a class of dangerous imvoluntarily committed mental patients, where the Third Circuit held that psychotropic drugs may be constitutionally administered "whenever, $\mathrm{m}$ the exercise of professional judgment, such an action is deemed necessary to prevent the patient froin endangering himself or others."112

Similarly, the district court in Rogers $v$. Okin ${ }^{113}$ acknowledged a pohice power justification for the forced administration of psychotropic drugs. The court determined that involuntarily committed mental patients "may be forcibly medicated in an emergency situation in which a failure to do so would result in a substantial likehihood of physical harm to that patient, other patients, or to staff members of the institution."114 On appeal, the First Circuit upheld the district court's determination that the state's police power interest was sufficient to outweigh the patient's right to refuse medication. ${ }^{115}$ The opinion, however, criticized the district court's formulation as a "simplistic unitary standard for pohice power einergency drug administration," "116 and instead adopted an ad hoc balancimg approach to be apphed by qualified state physicians. ${ }^{117}$ The state's interest in forced admimistration of drugs "must be to further its pohce power interests, i.e., the decision must be the result of a determination that the need to prevent violence in a particular situation out-

110. Okin, 634 F.2d at 658-59; Winters, 446 F.2d at 68; Davis, 506 F. Supp. at 935-36; People v. Medina, 705 P.2d 961, 973 (Colo. 1985) (en banc).

Where, however, the state civil commitment statute is read to condition commitment on a finding that the individual is incompetent to make treatment decisions and is in need of treatment, a mental hospital facility may constitutionally treat him involuntarily following commitment. Stensvad v. Reivitz, 601 F. Supp. 128 (W.D. Wis. 1985).

111. Harper, $110 \mathrm{~S}$. Ct. at 1039-40.

112. Rennie v. Klem, 720 F.2d 266, 269 (3d Cir. 1983) (en banc).

113. 478 F. Supp. 1342 (D. Mass. 1979), aff'd in part, rev'd in part, vacated \& remanded, 634 F.2d 650 (1st Cir. 1980), vacated \& remanded sub nom Mills v. Rogers, 457 U.S. 291 (1982).

114. Id. at 1365 .

115. Rogers v. Okin, 634 F.2d 650, 656-57 (1st Cir. 1980), vacated \& remanded sub nom. Mills v. Rogers; 457 U.S. 291 (1982).

116. Id. at 656 .

117. Id. at 657 . 
weighs the possibility of harm to the inedicated individual."118

In Bee v. Greaves, ${ }^{119}$ the Tenth Circuit held that an einergency situation might justify the forced administration of a psychotropic agent in order to maintain security and prevent a inentally ill prisoner froin injuring himself and others. "Determining that an emergency exists sufficient to warrant involuntary medication with this type of drug requires a professional judgment-call that includes a balancing of the jail's concerns for the safety of its occupants against a detainee's interest in freedoin from unwanted antipsychotics."120 Such a decision "Inust be the product of professional judgment by appropriate inedical authorities, applying accepted medical standards," and "requires an evaluation im each case of all the relevant circumstances, including the nature and gravity of the safety threat, the characteristics of the individual involved, and the likely effects of particular drugs." 121

Other courts have acknowledged that the state's police power interest in protecting institutional staff and other occupants from violence nay be sufficiently coinpelling to justify involuntary drug administration in einergency situations. ${ }^{122}$ However, courts have held other asserted police power interests imsufficient to outweigh the individual's constitutionally protected interest $\mathrm{m}$ refusing psychotropic medication. Considerations of converience and cost have been rejected, ${ }^{123}$ as has the state's interest in allowing the inedical profession to provide treatinent without unreasonable intrusion. ${ }^{124}$

\section{Washington v. Harper}

In 1976, Walter Harper was found guilty of robbery and sentenced to prison. Four years later, he was released on parole, but his parole was later revoked after he assaulted two nurses im a hospital. Upon his returu to prison, Harper was housed in the Special Offender Center, a special prison for prisoners with inental problems or behavioral disorders.

118. Id. at 656 (emphasis added).

119. 744 F.2d 1387 (10th Cir. 1984), cert. denied, 469 U.S. 1214 (1985).

120. Id. at $1395-96$.

121. Id. at 1396.

122. E.g., Gilliam v. Martm, 589 F. Supp. 680, 682 (W.D. Okla. 1984); Weiss v. Missouri Dep't of Mental Health, 587 F. Supp. 1157, 1161 (E.D. Mo. 1984); Project Release v. Prevost, 551 F. Supp. 1298, 1309 (E.D.N.Y. 1982), aff'd, 722 F.2d 960 (2d Cir. 1983); Davis v. Hubbard, 506 F. Supp. 915, 934-38 (N.D. Ohio 1980); People v. Medina, 705 P.2d 961, 973-74 (Colo. 1985) (en banc); Rogers v. Commissioner of Dep't of Mental Health, 390 Mass. 489, 510-11, 458 N.E.2d 308, 321-22 (1983); Opinion of the Justices, 123 N.H. 554, 560, 465 A.2d 484, 489 (1983); In re K. K. B., 609 P.2d 747, 750 (Okla. 1980).

123. See, e.g., Davis, 506 F. Supp. at 937; Rogers v. Okin, 478 F. Supp. 1342, 1370-71 (D. Mass. 1979), aff'd in part, rev'd in part, vacated \& remanded, 634 F.2d 650 (1st Cir. 1980), vacated \& remanded sub nom. Mills v. Rogers, 457 U.S. 291 (1982).

124. Davis, 506 F. Supp. at 937. 
Officials at the Center diagnosed Harper as suffering from mental illness, but the psychiatrist who made the diagnosis could not determine whether the illness was manic depression, a schizo-affective disorder, or schizophremia. The psychiatrist did, however, prescribe antipsychotic medication for Harper which, for a time, he agreed to take. According to Harper, he suffered adverse side effects from the medication, although the treatment staff claimed that he exaggerated or feigned most of his complanits. Eveutually, Harper refused to contmue taking the medication, and the treatment staff initiated proceedings to require him to do so. ${ }^{125}$

Sometime after prison officials decided to administer psychotropic drugs forcibly, Harper filed suit under the federal Civil Rights Act in an effort to stop the administration of the drugs. Harper claimed that the involuntary administration of psychotropic drugs without a prior judicial hearing violated his liberty imterest under the due process, equal protection, and free speech clauses of the federal and Washington state constitutions. ${ }^{126} \mathrm{He}$ argued that the due process clause demanded a judicial finding of incompetency and a "substituted judgment" by the court that, if competent, he would have consented to the treatmeut, before the state could involuntarily administer the drugs. ${ }^{127}$

The trial court rejected these claims, finding that the procedural safeguards provided by the State of Washington afforded Harper the requisite due process. ${ }^{128}$ On appeal, the Washington Supreme Court reversed, holding that Harper was entitled to a judicial hearing-with such attendant safeguards as the right to counsel, to present evidence, to cross-examine witnesses, and to remam silent-before he could be forced to take antipsychotic medication. ${ }^{129}$ The court also held that the burden was on the government at the hearing to prove by "clear, cogent, and convincing" evidence that a compelling state interest required the compulsory administration of drugs. ${ }^{130}$

The United States Supreme Court reversed. ${ }^{131}$ Although it recog-

125. Washington y. Harper, 110 S. Ct. 1028, 1032-33 (1990).

126. Id. at 1034. Harper made no eighth amendment claims. The Washington Supreme Court ruled in Harper's favor on due process grounds, and, therefore, did not address his equal protection or free speech claims. Harper v. State, 110 Wash. 2d 873, 876 n.2, 759 P.2d 358, 361 n.2 (1988), rev'd, 110 S. Ct. 1028 (1990); Harper, 110 S. Ct. at 1035 n.5.

Goedeeke v. State Department of Institutions, 198 Colo. 407, 603 P.2d 123 (1979), may have been the first case to declare that individuals have a right to refuse psychotropic drugs. Guthiel \& Appelbauin, supra note 20, at 80; see Birnbaum, The Right to Treatment, 46 A.B.A. J. 499, 500 (1960); Milleman, Protected Inmate Liberties: A Case for Judicial Responsibility, 53 OR. L. REv. 40 (1973).

127. Harper, $110 \mathrm{~S}$. Ct. at 1037.

128. Id. at 1034; Harper, 110 Wash. $2 \mathrm{~d}$ at $875-76,759$ P.2d at 361 .

129. Harper, 110 Wash. $2 \mathrm{~d}$ at $882-84,759$ P.2d at 364-65.

130. Id. at 884,759 P.2d at 365 .

131. Harper, $110 \mathrm{~S}$. Ct. at 1035. 
nized a constitutional hiberty interest in refusmg psychotropic medication, the Court found that the State of Washington had in fact provided adequate due process protection of that right. ${ }^{132}$ The state's policy required that a decision to inedicate an inmate imvoluntarily be inade by a committee coinposed of a psychiatrist, a psychologist, and an official of the state mental facility. Involvement $m$ the inmate's treatinent or diagnosis disqualified any potential committee member. The inmate's procedural rights included the following: the right to notice of the committee's hearing; the right to attend, present evidence, and crossexamine witnesses; the right to representation by a disinterested lay advisor versed in the psychological issues; the right to appeal to the Special Offender Center's superintendent; and the right to periodic review of any involuntary inedication ordered. State law also granted him the right to state court review of the coinmittee's decision. ${ }^{133}$

The Supreine Court found these administrative hearing procedures sufficient to coinport with procedural due process, holding that the due process clause does not require a judicial hearing before the state inay treat a inentally ill prisoner with psychotropic drugs against his will. ${ }^{134}$ Harper's liberty interest, when balanced against the governmental interest involved and the efficacy of the particular procedural requirements, was, in the Court's view, adequately protected by relegating the decision to administer drugs to inedical professionals rather than to a judge. ${ }^{135}$

Although it found the state adinmistrative scheme constitutional under the due process clause of the fourteenth annendment, the Court unequivocally deterinined that prisoners have a liberty interest "protected by the Due Process Clause, which permits refusal of anti-psychotic drugs unless certain preconditions are met." ${ }^{136}$ The Court left open the door to case-by-case scrutiny of the procedures under which states subject prisoners to involuntary drug treatment. Thus, at least one valid basis of constitutional attack still hes in the application of traditional procedural due process analysis to the mvoluntary admimistration of psychotropic drugs.

\section{The Least Restrictive Alternative}

The Court in Harper did not formulate the issue in terins of the less restrictive alternatives available to the State of Washington. The inajority simply rejected in passing the alternative ineans which Harper

132. Id. at 1044 .

133. Id. at 1040 .

134. Id. at 1042 .

135. Id.

136. Id. at 1040 
presented. ${ }^{137}$ Harper failed, Justice Kennedy wrote, to demonstrate adequate consideration of the state's interest; he failed to show that physical restraint or seclusion could effectively replace antipsychotic drugs when considering medical effectiveness or costs to the prisons. ${ }^{138}$

Unlike Harper, earlier right-to-refuse cases had required hospitals, under the least restrictive alternative doctrine, to consider less intrusive therapeutic metlods before administering a inetlod rejected by the patient. The Minnesota Supreme Court, in Price v. Sheppard, ${ }^{139}$ for exainple, considered the use of intrusive forins of treatment, sucli as electroshock therapy or psychosurgery, on involuntarily committed mental patients. The court reasoned that a court autliorizing these treatnients inust determine the reasonableness and necessity of the proposed treatinent in liglit of the availability of less intrusive treatments. ${ }^{140}$

In Rogers v. Okin, ${ }^{141}$ a federal circuit court recognized the applicability of the least restrictive alternative doctrine in the context of involuntary antipsychotic treatment. The court ultimately required that inedication decisions be the product of a "professional judgnient-call" following a balancing of the relevant state and individual interests. ${ }^{142}$ The court noted, lowever, that "reasonable alternatives to the adninistration of antipsycliotics inust be ruled out. Otherwise, the administration of the drugs would not be necessary to accomplisli the state's objective. Indeed, it may be possible that in most situations less restrictive ineans will be available."143

The Third Circuit also reviewed the constitutional standards governing the clain of a inentally retarded patient to freedom from institutional harm and undue pliysical restraint. The en banc court in Romeo $v$. Youngberg ${ }^{144}$ determined that institutional defendants had to demonstrate that the restraints imposed were the "least restrictive nuethod" of

137. Id. at 1039.

138. Id.

139. 307 Minn. 250, 239 N.W.2d 905 (1976).

140. Id. at 258,239 N.W.2d at 911 .

141. 634 F.2d 650, 656 (1st Cir. 1980), vacated \& remanded sub nom. Mills v. Rogers, 457 U.S. 291 (1982).

142. Id. at 655 .

143. Id. at 656. Many other courts have applied the doctrine of least restrictive alternative in the context of forced administration of psychotropic medication. See, e.g., Bee v. Greaves, 744 F.2d 1387, 1396 (10th Cir. 1984), cert. denied, 469 U.S. 1214 (1985); Osgood v. District of Columbia, 567 F. Supp. 1026, 1031 (D.D.C. 1983); People v. Medima, 705 P.2d 961, 974 (Colo. 1985) (en banc); Rogers v. Commissioner of Dep't of Mental Health, 390 Mass. 489, 510-11, 458 N.E.2d 308, 321 (1983).

144. 644 F.2d 147 (3d Cir. 1980) (en banc), vacated, 457 U.S. 307 (1982). Physical restraint is, of course, a different matter than psychotropic medication. See Medina, 705 P.2d at 968. A study of Romeo, however, is relevant by analogy for that court's application of the least restrictive means analysis. 
handling the patient, ${ }^{145}$ and that the treatment selected was the "least intrusive alternative" available. ${ }^{146}$

The United States Supreme Court subsequently vacated this judgment, adopting mstead the approach urged by Chief Judge Seitz in his eartier concurring opinion for the Third Circuit panel that decided Romeo. The Supreine Court opted for a deferential "professional judgment" standard, under which hability would lie only where "the decision by the professional is such a substantial departure from accepted professional judgment, practice, or standards as to demonstrate that the person responsible actually did not base the decision on such a judgment."147

In a post-Youngberg decision, the Tenth Circuit considered the application of the least restrictive alternative standard to the right to refuse treatınent, where pretrial detainees challenged the forcible administration of antipsychotic drugs. The court adopted the following standard: "[L]ess restrictive alternatives, such as segregation or the use of less controversial drugs like tranquilizers or sedatives, should be ruled out before resorting to antipsychotic drugs," where the purpose is to protect jail staff and other inmates from a violent detainee. ${ }^{148}$ The court recognized that the Supreme Court in Youngberg had declined to apply the "least restrictive alternative" standard. But Youngberg was distinguishable, the Tentl Circuit said, "both because it involved temporary physical restraints rather than mental restraints with potentially long term effects, and because [the patient there] had been certified as severely retarded and unable to care for himself." 149

Both distinctions are persuasive. Psychotropic drugs are more intrusive than the brief use of physical restraints. ${ }^{150}$ The restraints involved in Youngberg were "soft" restraints, applied only to the arms ${ }^{151}$ for short periods of tine, to prevent tlie patient from harming himself or others. ${ }^{152}$ Moreover, the use of physical restraints in Youngberg may have served the patient's best interests. ${ }^{153}$ Indeed, the patient, being "profoundly retarded," clearly lacked the capacity to assert that his best

145. Romeo, 644 F.2d at $160-61$

146. Id. at 166 .

147. Youngberg v. Romeo, 457 U.S. 307, 323 (1982).

148. Bee v. Greaves, 744 F.2d 1387, 1396 (10th Cir. 1984), cert. denied, 469 U.S. 1214 (1985).

149. Id. at $1396 \mathrm{n} .7$ (citations omitted).

150. See People v. Medina, 705 P.2d 961, 968 (Colo. 1985) (en banc) ("The effects of these drugs can be far more debilitating to the patient than the physical restraint incident to the involuntary commitment process." (footnote omitted)).

151. Youngberg, 457 U.S. at 310 n.4.

152. Id. at $311 \mathrm{n.8}$.

153. Cf. id. at 324 (state may restrain patients for safety or to provide such training as may reduce future necessity for restraints and future violence, and "as an appropriate professional would consider reasonable to ... f facilitate [the] ability to function free from bodily restraints"). 
interests diverged from the professional judgment of state physicians. ${ }^{154}$ By contrast, the detainee involved in Bee v. Greaves had never been declared mentally incompetent, and the court recogmized that he may have been wrongly treated. ${ }^{155}$ Mentally competent prisoners are capable of participating in treatment decisions, and courts should defer to the expressed preferences of prisoners hike Bee, and even prisoners with marginal competency. ${ }^{156}$ Respect for individual autonomy commands that deference. $^{157}$

The imphications of the Supreme Court's Youngberg decision for the apphicability of the least restrictive alternative principle to the right to refuse psychotropic drugs remains in doubt. The "professional judgment" standard enunciated by the Supreine Court in Youngberg ${ }^{158}$ cautions against undue judicial interference with state processes in an area inarked by the need for clinical judgment. Although Youngberg disfavors judicial second-guessing of mental health professionals, ${ }^{159}$ the imtrusive nature of psychotropic drugs may justify more judicial scrutiny than was considered appropriate in the context of Youngberg.

The individual's imterest in being free froin unreasonable physical restraints simply does not rise to the level of the interest in being free from the bodily and inental intrusions caused by psychotropic drugs, particularly in hight of their distressing side effects. While physical restraints certainly intrude on the constitutional privacy interest of bodily integrity and personal security, their effects are short-lived when contrasted with the longer-term effects of psychotropic drugs. Drugs therefore constitute a significantly greater intrusion. Drugs affect mental processes, and thus implicate first amendment values. Physical restraints, on the other hand, do not.

The Supreme Court's post-Youngberg/pre-Harper decision, Winston $v$. Lee, ${ }^{160}$ suggests that the least restrictive alternative doctrine may survive Youngberg in cases where the intrusion is more serious than the short-term use of physical restraints. In Winston, the Court found that a proposed surgical operation to remove a bullet from a criminal suspect's body imphicated the fourth amendinent's proscriptions against unreason-

154. Id. at 309.

155. 744 F.2d at 1395 ("Absent legitimate government objectives . . . we belicve that involuntary medication may itself amount to unconstitutional punishment.").

156. Cf. Winick, Restructuring Competency to Stand Trial, 32 UCLA L. Rev. 921, 965-67 (1985) (because competency is difficult to ascertain, we should continue to presume that anyone able to express a choice is competent).

157. See generally id. (high value attached to the principle of individual autonomy creates the presumption that an individual able to express a choice is competent, compelling acceptance of that choice).

158. Youngberg v. Romeo, 457 U.S. 307, 321-23 (1982).

159. Id. at 323 .

160. 470 U.S. 753 (1985). 
able searches and seizures. ${ }^{161}$ The Court found that the state's interest in surgery - to obtain evidence of guilt-was unreasonable in light of the uncertainty of the medical risks, the intrusion on plaintiff's privacy interests and bodily integrity, and the availability of substantial evidence of the defendant's guilt. ${ }^{162}$ The Court found that the "surgery involve[d] a virtually total divestinent of respondent's ordinary control over surgical probing beneath his skin." 163 The intrusion presented by psychotropic medication (a total divestment of control) is more like the procedure involved in Winston than the physical restraints involved in Youngberg. Thus the Winston approach, which considers alternative means to accomplish the state's compelling ends, is more appropriate.

At the very least, to comport with professional judgment standards, state prison physicians should consider the availability of less intrusive treatment alternatives. ${ }^{164}$ So long as state prison physicians give appropriate consideration to such alternatives, courts need not review the substance of these discretionary determinations. The approach should resemble one generally used in the administrative law context. In that setting, the reviewing courts examine agency determinations under a narrow standard of review, such as a "substantial evidence test" or an "arbitrary, capricious, abuse of discretion standard." With this approach, as long as the prison considers the appropriate factors, employs fair procedures, and does not reach a wholly irrational decision, the court will not disturb the substantive determination reached. This approach permits the judiciary to protect fundanental constitutional rights while deferring to the expertise of state physicians and therapists who are making essentially clinical judgments.

\section{B. Privacy}

Harper recognized that competent prisoners have a constitutionally protected liberty interest in refusing medication, an interest not lost by virtue of their incarceration. The Court, however, went on to hold that Harper's interest was outweighed by the state's imterest in safety and security ${ }^{165}$ and by the state's "duty to take reasonable measures for the prisoners' own safety."166 As discussed, the Court rejected Harper's due process clain, holding that the Special Offender Center pohicy was sufficient to guarantee due process, in hight of the competing interests of the

161. Id. at 758-63.

162. Id. at 763-66.

163. Id. at 765 .

164. See Rennie v. Klein, 720 F.2d 266, 272 (Adams, J., concurring, joined by Becker, J.), 274

(Seitz, C.J., concurring) (3d Cir. 1983).

165. Washington v. Harper, 110 S. Ct. 1028, 1036-40 (1990).

166. Id. at 1039. 
state. $^{167}$

There is, however, a broader constitutional basis upon which to predicate an inmate's right to refuse. Implied in the Court's recognition of Harper's liberty interests ${ }^{168}$ is a privacy argument which was not directly before the Court in Harper. This privacy interest provides anotlier basis for tlie riglit to refuse.

The security of one's person from state control is "[a]mong the historic hiberties" 169 whicl liave been recognized for centuries as part of the private sphere of individual liberties. ${ }^{170}$ The right of a coinpetent adult to refuse medical treatment "is an aspect of liberty requiring the lighest order of protection." 171 It is a fundainental principle that "[e]very huinan being of adult years and sound mind lias a right to deternine what sliall be done witl his own body."172

As was discussed in the previous Section, the psychotropic inedications at issue liere are far worse tlian, for example, the surgery rejected in Winston v. Lee. ${ }^{173}$ Drugs are more imtrusive because they are ongoing; they are used over a period of years and may liave severe and perinanent consequences. They affect the brain and intrude upon the inental processes. It is particularly significant that the intrusion is involuntary, even tliouglı the medication is arguably beneficial. The state in effect takes control of a prisoner's body as well as lier mind. This kind of intrusion mvolves the total divestment of tlie prisoner's control over probing of her body. ${ }^{174}$

Nearly a decade ago, in Mills $v$. Rogers, the Supreme Court nearly resolved the applicability of constitutional principles to treatınent witl psychotropic drugs. ${ }^{175}$ Altlough the parties agreed that the Constitution "recognizes a liberty interest im avoiding the unwanted administration of antipsychotic drugs," 176 the Court declined to resolve the issue in liglit of an intervening decision by the Supreme Judicial Court of Massachusetts recognizing a riglit to refuse psycliotropic drugs as a matter of state law in a related context. ${ }^{177}$

167. Id. at $1040-44$.

168. Id. at 1041.

169. Ingraham v. Wright, 430 U.S. 651,673 (1977).

170. See 1 W. Blackstone, COMMENTARIES *127-29; Ingraham, 430 U.S. at 673 n.41.

171. Harper, $110 \mathrm{~S}$. Ct. at 1056 (Stevens, J., concurring in part and dissenting in part).

172. Schloendorff v. Society of N.Y. Hosp., 211 N.Y. 125, 129, 105 N.E. 92, 93 (1914) (Cardozo, J.), overruled on other grounds by Bing v. Thunig, 2 N.Y.2d 656, 143 N.E.2d 3, 163 N.Y.S.2d 3 (1957).

173. 470 U.S. 753 (1985).

174. Id. at 765 .

175. 457 U.S. 291 (1982).

176. Id. at 299.

177. Id. at 300-05. 
In 1989, in Skinner v. Railway Labor Executives Association, ${ }^{178}$ the Court recognized that the fourth amendment "guarantees the privacy, dignity, and security of persons agamst certain arbitrary and invasive acts by officers of the Government or those acting at their direction."179 The coinpelled administration of a blood test ${ }^{180}$ and surgery to reinove a bullet froin a suspect's body ${ }^{181}$ have raised issues of privacy under the fourth amendment. The involuntary intramuscular injection of antipsychotic inedications into the body of a prisoner infringes upon an expectation of privacy in the same way as other physical imtrusions into the body. ${ }^{182}$ Although a prisoner may have no reasonable expectation of privacy in his cell, ${ }^{183}$ prisoners do have a reasonable expectation that the privacy of their bodies and their minds will not be physically invaded by the state. ${ }^{184}$

Justice Kennedy recognized the prisoner's privacy right in Harper, relying several times upon Vitek $v$. Jones, ${ }^{185}$ where the Court had earher held that there was a protected liberty interest in avoiding transfer froin a prison to a mental hospital. "[T]he stigniatizing consequences of a transfer to a inental hospital for involuntary psychiatric treatment, coupled with the subjection of the prisoner to inandatory behavior modification as a treatment for inental illness, constitutes the kind of deprivations of liberty that requires procedural protections." 186

The Vitek Court did not address the possibility of forced treatinent with psychotropic drugs. However, such treatment is a far greater intrusion on privacy than the behavior inodification at issue in Vitek, because the latter does not touch the body and has no chemical effect on the brain. Discussing the "grievous loss" incurred by an inmate transferred to a mental hospital and subjected to behavior inodification, the Court noted that the due process clause would protect an ordinary citizen subjected to these consequences. ${ }^{187}$ The Court concluded that "a convicted

178. 109 S. Ct. 1402 (1989).

179. Id. at 1411 (citing Camara v. Municipal Court, 387 U.S. 523, 528 (1967)). The fact that the intrusion was effected by a private party did not preclude its consideration as a fourth amendment issue, because the private party acted as "an instrument or agent of the Goverument." Id.

180. Schmerber v. California, 384 U.S. 757, 767 (1966).

181. Winston v. Lee, 470 U.S. 753, 759-60 (1985).

182. See Skinner, $109 \mathrm{~S}$. Ct. at 1412.

183. Hudson v. Palmer, 468 U.S. 517, 530 (1984).

184. Skinner, 109 S. Ct. at 1412; Bell v. Wolfish, 441 U.S. 520, 558-60 (1979) (permitting visual searches of body cavities where the inmate is not touched); Houchins v. KQED, Inc., 438 U.S. 1, 5 n.2 (1978) ("Inmates in jail, prisons, or mental institutions retain certain fundamental rights of privacy; they are not like animals in a zoo to be filmed and photographed at will by the public or by media reporters, however 'educational' the process may be for others.").

185. 445 U.S. 480 (1980).

186. Id. at 494.

187. Id. at 492 . 
felon also is entitled to the benefit of procedures appropriate in the circumstances before he is found to have a mental disease and transferred to a mental hospital."188 If the transfer to a inental hospital in Vitek was not "within the range of conditions of confinement to which a prison sentence subjects an individual," 189 then nor should the inore intrusive forced administration of psychotropic drugs be within that range. The liberty interest that protects prisoners and ordinary citizens alike provides a basis for the prisoner's rejection of the unwanted adıninistration of psychotropic medication.

Finally, the right to privacy includes the right to make one's own medical decisions, ${ }^{190}$ which is not extinguished upon becoming a prisoner. Both federal and state courts have recognized the right of a prisoner ${ }^{191}$ or pretrial detainee ${ }^{192}$ to inake his or her own medical decisions. It is axiomatic that "convicted prisoners do not forfeit all constitutional protections by reason of their conviction and confinement in prison, and that they may claim the protection of the Due Process Clause to prevent additional deprivation of life, hiberty or property without due process of law."193

Indeed, both the federal and state courts have consistently recog. nized the existence of at least a qualified right to refuse treatment with psychotropic drugs. ${ }^{194}$ In view of the effect of the drugs on mental processes and bodily integrity, this result seenis clearly justified.

\section{First Amendment}

Mental health treatments that coerce beliefs, attitudes, and inental processes implicate first amendment principles. The Supreme Court has broadly construed the first amendment protection of freedoin of speech

188. Id. at 493 .

189. Id.

190. Doe v. Bolton, 410 U.S. 179, 213, 219 (1973) (Douglas, J., concurring).

191. Runnels v. Rosendale, 499 F.2d 733, 735 (9th Cir. 1974) (prisoner's constitutional right to be secure in the privacy of his or her body against invasion by the state may be violated in the course of treatment by prison medical personnel); Doe v. Coughlin, 697 F. Supp. 1234, 1241 (N.D.N.Y. 1988) (prisoners testing positive for the HIV virus retain a constitutional privacy right to choose whether to be housed in a separate dormitory); Keyhea v. Rushen, 178 Cal. App. 3d 526, 542, 223 Cal. Rptr. 746, 755-56 (1986) (prisoners entitled to judicial determination of competency to refuse treatment); Zant v. Prevatte, 248 Ga. 832, 834, 286 S.E.2d 715, 717 (1982) (prisoner on hunger strike retains right of privacy to refuse forced feeding, cven though it is intended to save his life).

192. Bee v. Greaves, 744 F.2d 1387, 1394 (10th Cir. 1984), cert. denied, 469 U.S. 1214 (1985).

193. Bell v. Wolfish, 441 U.S. 520, 545 (1979) (citations omitted).

194. For federal law, see, for example, Washington v. Harper, $110 \mathrm{~S}$. Ct. 1028, 1036 (1990); United States v. Charters, 863 F.2d 302, 305-06 (4th Cir. 1988) (en banc), cert. denied, 110 S. Ct. 1317 (1990); Project Release v. Prevost, 722 F.2d 960, $977-79$ (2d Cir. 1983). For state cases, see, for example, Jarvis v. Levine, 418 N.W.2d 139, 148-49 (Minn. 1988); Rivers v. Katz, 67 N.Y.2d 485, 492-93, 495 N.E.2d 337, 341, 504 N.Y.S.2d 74, 78 (1986); Opinion of the Justices, 123 N.H. 554, 559-60, 465 A.2d 484, 489 (1983); In re K. K. B., 609 P.2d 747, 749 (Okla. 1980); In re Boyd, 403 A. $2 \mathrm{~d} 744,749$ (D.C. 1979). 
to include protection of a nuinber of corollary rights that, although not expressly named in the Constitution, are deemed indispensable to the exercise of free speech. These include freedom of association, ${ }^{195}$ the right to receive information and ideas, ${ }^{196}$ and the right to make a monetary contribution to an organization for the purpose of spreading a political message. ${ }^{197}$ The Court has found these rights necessary to protect the purposes underlying the first amendment. Language in a number of the Court's opinions in contexts other than forced treatment suggests that first amendment protection also extends to freedom of thought and freedom of behief. ${ }^{198}$ The Court has noted that "at the heart of the First Amendment is the notion that ... one's behefs should be shaped by his mind and his conscience rather than coerced by the State." 199 Coercive mental health treatinent techniques certainly imphicate these values. ${ }^{200}$

Certainly, the primary effects of psychotropic drugs can be described as restorative or normalizing. They do not create thoughts, and it inay be misleading to describe them as "controlling the mind" in a significant way. They are, however, undeniably mind-altering, and effect changes in inental processes without the cooperation of the patient. The effects of these drugs on recipients and on recipients' mental processes have led many courts to determine that the first amendment is implicated. $^{201}$ A number of state and lower federal courts have apphied first amendment primciples in recognizing a right to refuse intrusive mental health treatinent. Because the first amendment protects freedom of

195. See NAACP v. Alabama ex rel. Patterson, 357 U.S. 449, 460 (1958) (close nexus between the freedoms of speech and assembly).

196. Board of Educ. v. Pico, 457 U.S. 853, 866-67 (1982).

197. Buckley v. Valeo, 424 U.S. 1, 22-23 (1976).

198. See, e.g., Whitney v. California, 274 U.S. 357, 375 (1927) (Brandeis, J., concurring) (freedom to think as you will indispensable to discovery and spread of political truth), overruled by Brandenburg v. Ohio, 395 U.S. 444, 479 (1969) (holding that Whitney contained unduly broad condemnation of free speech in context of syndicalisin law); Cantwell v. Connecticut, 310 U.S. 296, 303 (1940) (freedom to believe and freedom to act).

199. Abood v. Detroit Bd. of Educ., 431 U.S. 209, 234-35 (1977).

200. In a case reversing a conviction for possession of obscene inaterial, for example, the Court held that the first amendinent prohibits inaking the private possession of obscenity a crime. Stanley v. Georgia, 394 U.S. 557 (1969). In broad language, the Court stated that "[o]ur whole constitutional heritage rebels at the thought of giving governinent the power to control individuals' minds"; a right of the state "to control the inoral content of a person's thoughts," the Court noted, was "wholly inconsistent with the philosophy of the first amendment." Id. at 565-66. Intrusive therapies that "control" the inind are sinilarly offensive to the first amendment.

201. In Scott v. Plante, 532 F.2d 939 (3d Cir. 1976), vacated and remanded, 458 U.S. 1101 (1982), for example, the Third Circuit lield that the "involuntary adininistration of drugs which affect inental processes ... could amount, under an appropriate set of facts, to an interference with [the patient's] rights under the first amendinent." Id. at 946.

In Bee v. Greaves, 744 F.2d 1387, 1394 (10th Cir. 1984), cert denied, 469 U.S. 1214 (1985), involving pretrial detainees forcibly subjected to antipsychotic inedication, the Tenth Circuit recognized a first amendinent right to refuse treatment, because such drugs could affect the ability to think clearly and to cominunicate. Id. at 1393-94. 
expression, these courts reason, it must also protect the more basic right to formulate and maintain ideas.

The first case to apply the first amendment in this context was Kaimowitz v. Michigan Department of Mental Health. ${ }^{202}$ The defendant, charged with rape and murder, was held in a state mental hospital under the Michigan sexual psychopath statute. When the state sought to involve him in a research study of experimental psychosurgery for the treatment of uncontrollable aggression, suit was filed to enjoin the state action. Finding that psychosurgery is clearly experimental and exposes research subjects to substantial and in some cases unknown dangers, the court determined that imposition of psychosurgery would violate the first amendinent. Finding that psychosurgery would seriously and irreversibly impair the freedom to generate ideas, the court declared: "Government has no power or right to control men's minds, thoughts, and expressions. . . . The State's interest in performing psychosurgery . . . must bow to the First Amendment, which protects the generation and free flow of ideas from unwarranted interference with one's mental processes." 203

Does psychotropic medication really intrude sufficiently upon mental processes to trigger first amendment scrutiny? The answer must be that it does. By defimition, psychotropic drugs affect one's mind, intellectual functions, perceptions, inoods and einotions. ${ }^{204}$ Indeed, the Supreme Court has acknowledged that the ability of these drugs to control behavior rests im their capacity to achieve such "mind-altering" effects. ${ }^{205}$ Psychotropic drugs directly imtrude on mental processes in a way the subject cannot resist.

Not only do the drugs work an alteration of mental processes, but the toxic reactions and other adverse side effects accompanying most of the drugs also frequently have debilitating effects on mental processes. ${ }^{206}$ Many of the physical side effects of psychotropic drugs, although not

202. 42 U.S.L.W. 2063 (Mich. Cir. Ct. 1973), reprinted in A. BrooKs, supra note 86, at 902-21.

203. Id. at 2064, reprinted in A. Brooxs, supra note 86, at 918 . In Mackey v. Procunicr, 477 F.2d 877 (9th Cir. 1973), prison officials administered anectine (succinylcholine), the "breath stopping and paralyzing 'fright' drug" described above, see supra text accompanying note 82, as part of a state prison aversive conditioning program. The recipient alleged that he regularly suffered nightmares in which he rehived the frightening experience and when he awakened he was unablc to breathe. Mackey, 477 F.2d at 877 . These allegations of mental intrusion and negative effect led the Ninth Circuit to determine that the prison practices raised serious constitutional questions. Id. at 878.

Not unlike the court in Mackey, the Seventh Circuit invoked the first amendment in Lojuk v. Quandt, 706 F.2d 1456 (7th Cir. 1983). The court found that the involuntary imposition of electroconvulsive therapy implicated the first amendment interest in free thought and communication. Id. at 1465.

204. Guthiel \& Appelbaum, supra note 20, at 79.

205. Mills v. Rogers, 457 U.S. 291, 293 n.1 (1982).

206. See supra notes $40-58$ and accompanying text. 
directly affecting inental processes, are so distressing that they frequently affect the ability to think clearly and to concentrate. Moreover, the emotional side effects of inany antipsychotic drugs, mcluding a "flattening" of the emotions which inanifests itself as boredom, histlessness, lethargy, purposelessness, and apathy, ${ }^{207}$ can indirectly affect the patient's inental processes by affecting motivation.

Thougli there may be a de minimis level of intrusion below which the courts will not apply first amendment scrutiny, a typical course of treatinent with psychotropic medication will pass any such threshold. ${ }^{208}$ Thus, it seeins likely that future courts will conclude that treatinent of prisoners with these drugs demands scrutiny under the first amendment.

\section{Cruel and Unusual Punishment}

\section{Eighth Amendment History}

The prohibition agamst cruel and unusual punishment first appeared in the English Bill of Rights of 1689, and was later incorporated into the Virginia Declaration of Rights in 1776. The autlor of the American constitutional provision appeared principally concerned witl methods of punishment. $^{209}$ In early cases such as In re Kemmler ${ }^{210}$ and Wilkerson $v$. $U t a h,{ }^{211}$ the Court interpreted the eighth amendment as a prohibition on extreme forins of corporal punishment. ${ }^{212}$ Early cases enunierated as cruel and unusual such punishments as beheadings, public dissection, burning at the stake, and crucifixion, and defined "cruel and unusual" by a fixed historical test used when the Bill of Rights was adopted. ${ }^{213}$

In 1910, the Supreine Court in Weems v. United States ${ }^{214}$ made a break from the previous inflexible interpretation, recognizing that the eiglith amendment slould be flexible and responsive to social norns. ${ }^{215}$

207. See supra note 41 and accompanying text.

208. See supra note 48 and accompanying text.

209. See generally Granucci, “'Nor Cruel and Unusual Punishment Inflicted': The Original Meaning", 57 CAL1F. L. REV. 839, 841-42 (1969) (discussing the framers' original intent).

210. 136 U.S. $436(1890)$.

211. 99 U.S. 130 (1879).

212. Kemmler, 136 U.S. at 446-47; Wilkerson, 99 U.S. at 136; see also Note, Constitutional Law-The Eighth Amendment and Prison Reform, 51 N.C.L. REv. 1539, 1540 (1973) (authored by Ronald H. Rosenberg) (eighth amendment's original purpose was to eliminate executions and torture).

213. Furman v. Georgia, 408 U.S. 238, 264 (1972) (Brennan, J., concurring).

214. 217 U.S. 349 (1910).

215. The Court wrote:

Legislation . . . is enacted, it is true, from an experience of evils, but its general language should not, therefore, be necessarily confined to the form that evil had theretofore taken. Time works changes, brings into existence new conditions and purposes. Therefore a principle to be vital must be capable of wider application than the mischief which gave it birth. This is peculiarly true of constitutions. They are not ephemeral enactments, designed to meet passing occasions. They are... "designed to approach immortality as nearly as human institutions can approach it." The future is their care and provision for 
Relying on Weems, recent cases have broadened the eighth amendment's scope by forbiddmg conduct that does not reach the point of physically barbarous punishment. ${ }^{216}$

\section{Medical "Treatment" As Punishment}

Eighth amendment protection applies to forced medication only if sucl conduct is deemed "punishment" within the confines of the amendment. $^{217}$ Since "treatment" is a medical term, referring to a procedure performed for the ultimate benefit of the patient, it is not subject to eighth amendinent scrutiny. The distinction between treatment and punishment, however, is not entirely clear.

Ingraham v. Wright ${ }^{218}$ presents the inost recent and extensive Supreine Court articulation of the coinplex distinction between treatment and pumshment. ${ }^{219}$ The Court in Ingraham declared that the eighth amendment was "designed to protect tlose convicted of crimes,"220 implying that its application was linited to crimmal punishment. ${ }^{221}$ In a significant footnote, lowever, the Court expressly reserved judgment on the potential application of the eighth amendment to health care practices:

Some punishments, though not labeled "criminal" by the State, may be sufficiently analogous to criminal punishments in the circumstances in which they are administered to justify application of the Eighth Amend-

events of good and bad tendencies of which no prophecy can be made. In the application of a constitution, therefore, our contemplation cannot be only of what has been but of what may be. Under any other rule a constitution would indeed be as easy of application as it would be deficient in efficacy and power. Its general principles would have little value and be converted by precedent into impotent and lifeless formulas. Rights declared in words inight be lost in reality. And this has been recognized. The meaning and vitality of the Constitution have developed against narrow and restrictive construction.

$\cdots$

... [The eighth amendmentl may be therefore progressive, and is not fastened to the obsolete but inay acquire meaning as public opinion beeones enlightened by a humane justice.

Id. at 373,378 .

216. See, e.g., Estelle v. Gamble, 429 U.S. 97, 102-04 (1976) (deliberate indifference to serious inedical needs constituted cruel and unusual punishment).

217. See Opton, Psychiatric Violence Against Prisoners: When Therapy Is Punishment, 45 Miss. L.J. 605, 607 (1974) (rejeeting the distinction between treatment and punishment); see also P. Breggin, Psychosurgery for the Control of Violence-Including a Critical Examination of the Work of Veruon Mark and Frank Ervin (1972), reprinted in 118 CoNG. REC. 11,396, 11,400 (1972) (discussing the potential interest of the state in the use of psychosurgery for other than therapeutic purposes).

218. 430 U.S. 651 (1977).

219. The Court's recent decision in Washington v. Harper, $110 \mathrm{~S}$. Ct. 1028 (1990), does not address whether forced administration of psychotropic drugs to prisoners constitutes cruel and unusual punishment, as the eighth amendment question was not presented by the parties.

220. Ingraham, 430 U.S. at 664.

221. See Winick, supra note 22, at 806 (interpreting Ingraham to limit eighth amendment protection to the context of criminal punishment). 
ment. We have no occasion in this case, for example, to consider whether or under what circumstances persons involuntarily confined in mental or juvenile institutions can claim the protection of the Eighth Amendment. 222

Ingraham suggests a two-part test that must be satisfied before the eighth amendment may be applied to liealtl care practices: first, the action taken must be a "punishment," and second, the circumstances surrounding the punishment must be analogous to those of a criminal pumshment. ${ }^{23}$ The following discussion will apply these standards to the involuntary medication of mentally ill prisoners.

The groundbreaking case of Estelle v. Gamble ${ }^{224}$ greatly broadened the traditional eighth amendment concept of pumshment. In Estelle, the Supreme Court found that behavior on the part of prison officials, though not inherently pumitive, nonetheless constituted cruel and unusual punishment. The case was brought by an inmate of a Texas state prison who claimed that prison officials violated his eighth amendment rights by depriving him of adequate medical treatment. The Court held that deliberate indifference to prisoners' serious medical probleins constituted an "unnecessary and wanton infliction of pain" and therefore violated the eighth amendment. ${ }^{25}$ The intentional demal or delay of proper inedical treatment by officials at the institution fell withm the Court's broadened concept of pumishment. ${ }^{226}$

If failure to give treatinent constitutes punishment, then active treatment agaimst an inmate's will should easily require eighth amendment scrutiny. Estelle lends strong support to the position that, in instances of involuntary medication of prisoners, it is the treatment itself that constitutes punishment and tlus warrants eighth amendment scrutiny. ${ }^{227}$

A further significant aspect of the case hes in the Court's finding of an eighth amendinent violation in an act of the state which was not in response to misbehavior. ${ }^{228}$ The official behavior was considered punishinent even though it was not necessarily admimstered punitively. Following this reasoning, psychotropic drugs involuntarily administered for control or treatment purposes should be subject to the eighth amend-

222. Ingraham, 430 U.S. at 669 n.37 (citation omitted).

223. Note, Right to Treatment for the Civilly Committed: A New Eighth Amendment Basis, 45 U. CHI. L. REv. 731, 741 (1978) (authored by Thomas D. Roberts).

224. 429 U.S. 97 (1976).

225. Id. at 104 (citing Gregg v. Georgia, 428 U.S. 153, 173 (1976) (joint opinion of Stewart, Powell \& Stevens, JJ.)).

226. Id. at 102-05; see Note, supra note 223 , at 747.

227. See Note, The Right Against Treatment: Behavior Modification and the Involuntarily Committed, 23 CATH. U.L. Rev. 774, 782-84 (1974) (authored by Edward J. Damich) (calling for application of the eighth amendment to all treatments imposed upon those involuntarily committed to mental institutions).

228. Note, supra note 223 , at $749-50$. 
ment, whether or not the drugs were dispensed in response to misbehavior.

Any distinction between treatment and punishment is particularly blurred in the prison context. As one scholar has argued:

[T] he disinclination of the courts to grapple with the probleins of violence by psychiatrists against prisoners represents a blind spot, the logical center of which is the insistence on a distinction between treatment and punishment.

... [I]t should not be surprising, therefore, if prison administrators have from time to time labeled as "treatment" acts which, if called "punishment," would be instantly recognized as of dubious morality or legality. 229

The same author cites the administration of inind-altering drugs as the most common instance of "legally sanctioned, punitive violence."230

In Sawyer v. Sigler, ${ }^{231}$ the district court weakened the distinction between treatment and punishment. Under prison policy, ${ }^{232}$ officials of the Nebraska Penal and Correctional Coinplex required William Sawyer to take his emphyseina medication in crushed or liquid form. Taking the medication in this form, however, nauseated Sawyer, and a prison physician therefore prescribed alternative forms of medication. Prison officials overruled the physician's recommendation. ${ }^{233}$ The district court found that a treatment resulting in nausea constituted cruel and unusual punishment, when under the circumstances alternative forms of treatment would not threaten the valid police power interests underlying the prison pohicy. ${ }^{234}$ This focus on the detrimental result of an imposed form of medical treatinent rather than on the form of treatment provides a stronger link between "treatment" and the "punishment" required to trigger eighth amendment protection. The likelihood of pain and other side effects produced by the drugs also supports the cliaracterization of their involuntary admimistration as punishinent.

The willingness of the United States Supreme Court in Trop $v$. Dulles $^{235}$ to find a state action substantively penal in nature could also be extended to characterize treatment as punisliment. In Trop, a private in the United States Army serving in French Morocco escaped from a

229. Opton, supra note 217 , at 607 .

230. Id. at 608 .

231. 320 F. Supp. 690 (D. Neb. 1970), aff'd, 445 F.2d 818 (8th Cir. 1971).

232. The policy requiring that all medication be administered in cruslied or liquid form was intended to prevent tlie prisoners from hoarding narcotics. Id. at 693.

233. Id.

234. Id. at 694; see Note, A New Perspective in Prisoners' Rights: The Right to Refuse Treatment and Rehabilitation, 10 J. Marshall J. Prac. \& Proc. 173, 184 (1976) (authored by Marc D. Ginsberg).

235. 356 U.S. 86 (1958). 
stockade. After less than a day, he willingly surrendered while returning to his base. He was subsequently deprived of his citizenship as a convicted deserter under the Nationality Act of 1940 . The Court held that the provision of the Act violated the eighth amendinent because it was penal in nature and constituted cruel and unusual punishment. ${ }^{236}$ The Court characterized denationalization as cruel and unusual punishinent because it constituted complete destruction of the individual's status in society, subjecting the individual to increasing fear and distress. ${ }^{237}$

The Court in Trop rejected the government's arguinent that because the statute was not classified as penal, constitutional limits on the state's power to pumish were inapphicable. The Court insisted that "form cannot provide the answer to this inquiry," but rather "[t]he inquiry must be directed to substance."238 The Court noted: "How simple would be the tasks of constitutional adjudication and of law generally if specific problems could be solved by inspection of the labels posted on thein."239 Just as the Court looked past the naturalization label to recognize the penal nature of the statute in Trop, so it could declare an action labeled "treatment" to be penal in nature, and therefore a "punishment" subject to eighth ainendinent scrutiny. ${ }^{240}$

Both the Sawyer "result" test and the Trop "purpose" test inay be used to include involuntary inedication within the scope of eighth amendment protection. The harmful side effects of inany of the psychotropic drugs discussed above, particularly the irreversible symptoms of tardive dyskinesia, are Sawyer-like "results" upon which many courts might look askance. In Knecht v. Gillman, ${ }^{241}$ the Eighth Circuit einployed the Trop "purpose" test. It found that pumishing a inental patient's misbehavior with the administration of apomorphime, which induced vomiting spells lasting from fifteen minutes to an hour, constituted cruel and unusual pumishinent. ${ }^{242}$ Such an analysis inay be particularly useful in cases where psychotropic drugs are given to prisoners for behavior control or staff convemence (a widespread practice), ${ }^{243}$ but without a therapeutic goal in mind.

236. Id. at 99-102 (plurality opmion). But see Bassett v. United States Immigration \& Naturalization Serv., 581 F.2d 1385, 1387-88 (10th Cir. 1978) (deportation is a civil proceeding and not cruel and unusual pumishment).

237. Trop, 356 U.S. at 101-02.

238. Id. at 95 .

239. Id. at 94 .

240. Note, supra note 227 , at 779 . In Trop, the Court concluded that if a statute had a legitimate governmental purpose other than punishment, it would be considered non-penal. In statutes with both a penal and non-penal effect, the statute's controlling nature was determined by its legislative purpose. Trop, 356 U.S. at 96.

241. 488 F.2d 1136, 1139-40 (8th Cir. 1973).

242. Id.

243. Opton, supra note 217 , at 623. 
The Eighth Circuit in Knecht was influenced by Inmates of the Boys' Training School v. Affleck, ${ }^{244}$ in which the district court grappled with a similar question and concluded: "The fact that juveniles are in theory not punished, but merely confined for rehabilitative purposes, does not preclucle operation of the Eighth Amendinent. The reality of confinement in Annex B is that it is pumishment. It is punishment imposed on obdurate boys by defendant administrators of the Training School."245

Similarly, the Seventh Circuit in Vann v. Scott ${ }^{246}$ considered an eighth amendment challenge to the practice of incarcerating runaway juveniles alongside serious delinquents. Like the Eighth Circuit in Knecht, the Vann court refuted purely semantic distinctions:

Whatever the state does with the child is done in the name of rehabilitation. Since-the argunent runs-by definition the treatinent is not "punishment," it obviously cannot be "cruel and unusual punishinent." But neither the label which a State places on its own conduct, nor even the legitimacy of its inotivation, can avoid the applicability of the Federal Constitution. We have no doubt that well intentioned attenipts to rehabilitate a child could, $\dot{n} 1$ extrene circunstances, constitute cruel and unusual punishment proscribed by the Eighth Amendment. ${ }^{247}$

Under this analysis, even a prison's legitimate attempt to "rehabilitate" a mentally ill prisoner with psychotropic drugs could constitute punishment.

Nelson v. Heyne ${ }^{248}$ furthered the attenuation of the treatmentpunishment distinction, and presents a remarkably close analogy to forced drug administration in prison facilities. In Nelson, juveniles in a correctional institution were forced to take the psychotropic agents Sparine and Thorazine, "not as part of an ongoing psychotherapeutic program, but for the purpose of controlling excited behavior."249 Similar reasons are often advanced to justify the adininistration of psychotropic medication to mentally ill adult prisoners. ${ }^{250}$ The court held that the involuntary medication constituted cruel and unusual punishinent, citing the potentially harmful side effects of the drugs similar to those previously described in this Comment including: "collapse of the cardiovas" cular systein, the closing of a patient's throat with consequent

244. 346 F. Supp. 1354 (D.R.I. 1972). Inmates challenged conditions at a juvenile corrections institution. The trial court reviewed the inadequate feeding schedule, deprivation of outdoor exercise, "inhuman solitary confinement cells," $i d$. at 1365, and other aspects of the institution, and held that the inmates' rights of due process, equal protection, and protection against cruel and unusual punishment were violated. Id. at 1366-67.

245. Id. at 1366 (emphasis omitted); see Knecht, 488 F.2d at 1139 \& n.6.

246. 467 F.2d 1235 (7th Cir. 1972).

247. Id. at 1240 .

248. 491 F.2d 352 (7th Cir.), cert. denied, 417 U.S. 976 (1974).

249. Id. at 356.

250. Opton, supra note 217 , at 640 (most drugging is for purposes of control). 
asphyxiation, a depressant effect on the production of bone marrow, jaundice from an affected liver, and drowsiness, hematological disorders, sore throat and ocular changes." ${ }^{251}$ In Nelson, though the drugs were introduced as treatment, the court found their administration was punishment.

There has been at least one court that has rejected this "treatment as punishment" theory, however. In refusing to uphold a claim that electroshock treatment administered to an involuntarily comınitted mental patient was cruel and unusual punishment, the Minnesota Supreme Court in Price v. Sheppard ${ }^{252}$ distinguished Knecht and Affleck on the grounds that in both cases the challenged conduct stemmed from a retributive objective. The court in Price found that the electroshock treatment was given for therapeutic reasons, with no deterrent or retributive goal, and not in response to a single behavioral imcident. ${ }^{253}$ The court also rehed upon Trop not to support, but to defeat, the eighth amendment challenge, finding the claim invalid where treatment serves a legitimate purpose. ${ }^{254}$

Price does not, however, necessarily define punishment for eighth amendment purposes. For example, the courts could, as did the Sawyer court, adopt a "result" test, and find that like electroconvulsive therapy, drug therapy may at times produce frightening and painful effects, which could result in a violation of the eighth amendinent-no matter how well-intentioned the therapeutic goals. Furthermore, the Price court's narrow reading of Knecht and Affleck was not mandated by the original wording of those opinions. Those decisions can be read in a less restrictive inanner so as not to preclude "non-retributive" conduct from eightlı amendment scrutiny. Fimally, some experts would claim that electroshock therapy does not in fact serve any legitimate purpose and may well be deleterious, ${ }^{255} \mathrm{~m}$ which case it would fail the purposive standard of the Trop test.

The broad definition of "punishment" for purposes of eighth amendment analysis used in the cases discussed above should include within its boundaries involuntary administration of psychotropic medication.

251. Nelson, 491 F.2d at 357 (footnote omitted).

252. 307 Minn. 250, 239 N.W.2d 905 (1976). Suit was brought by the mother of a minor who was involuntarily committed to a state mental hospital. The Supreme Court of Minnesota, in addition to rejecting the eighth amendment claim, found that the hospital director was immune from tort liability and liability under the federal Civil Rights Act. However, the court ordered that, before applying intrusive forms of treatment without the patient's consent, the state must appoint a legal guardian for the patient to represent her in a judicial adversary hearing to determine the necessity and reasonableness of the treatment. Id. at 262-63, 239 N.W.2d at 913.

253. Id. at 255,239 N.W.2d at 909.

254. Id., 239 N.W.2d at 909.

255. See, e.g., Giamartino, Electroconvulsive Therapy and the Illusion of Treatment, 35 Psychological Rep. 1127 (1974). 
With the weakening of the distinction between treatment and punishment, and the willingness of courts to look past the formal nature of an act to its substance, the mere labeling of such forced inedication as "treatinent" does not automatically remove it from the scope of the eighth amendinent. Although potential positive effects froin the drugs could be used to show the non-penal purpose of their administration as required by Trop, courts have recognized that even legitimate inotivations for official behavior does not deflect eighth amendinent scrutiny. ${ }^{256}$

\section{Judicial Standards for Determining Cruel and Unusual Punishment, and Their Application to Involuntary Medication in the Prison Context}

As the words of the eighth amendinent are not precise, nor is their scope static. ${ }^{257}$ The underlying principle of the amendinent "is not fastened to the obsolete, but may acquire meaming as public opinion becoines enlightened by a humane justice."258 The Supreme Court has recognized that "[t] $]$ he Amendinent must draw its meaning froin the evolving standards of decency that inark the progress of a maturing society."259

We discussed in the previous Section the ineaning of the words of the amendinent. The notion of punishment has evolved and should continue to evolve over time. This notion of flexibility is equally important when creating the standards for determining appropriate use of psychotropic drugs. These drugs are of relatively recent origin; thus, the extent and severity of their effects are not yet completely known. Judicial decisions concerning the constitutionality of the drugs' application will necessarily depend, in part, upon the continuing evolution of medical knowledge.

In addition, the societal attitude toward mental illness and its treatment is continually changing. Medical procedures once accepted as coinmonplace niay be regarded under conteniporary standards of morality as repulsive or barbaric. The performance of lobotonies, for example, once hailed by medical professionals as a revolutionary treatnient, has since fallen into great disfavor. ${ }^{260}$ Lobotony is the medical procedure by which doctors sever the nerve fibers (as of the fontal lobes) by incision into the brain. Lobotomy causes severe loss of inemory and loss of affection, insight, and values. ${ }^{261}$ Not surprisingly, lobotorny suffered a decline with the emergence of psychotropic drugs, ${ }^{262}$ although at least one

256. See, e.g., text accompanying note 247 .

257. Trop v. Dulles, 356 U.S. 86, 100-01 (1958) (plurality opinion).

258. Weems v. United States, 217 U.S. 349, 378 (1910).

259. Trop, 356 U.S. at 101 (plurality opinion).

260. Note, supra note 61 , at $656-57$.

261. Id. at 633 .

262. Comment, Informed Consent and the Mental Patient: California Recognizes a Mental 
author suggested as recently as the 1970s that lobotomy would make a comeback in the treatment of "drug addiction, hoinosexuality, frigidity, intolerable pain, crippling fear and schizophrenia."263

Similarly, electroconvulsive therapy, in which electric currents are applied to the front part of the individual's head (thus producing unconsciousness and convulsions), was once the treatment of choice in treating severe depression. The side effects of electroconvulsive therapy are severe: they include damaged muscles and brain tissue, broken bones, and loss of meinory. ${ }^{264}$ This therapy was once rationalized as necessary and humane in light of the seriousness of the mental disease and the effort to avoid even more drastic alternative therapies. ${ }^{265}$ Drug therapy, however, has beconie the therapy of choice for severe depression primarily because it is cheaper and easier to administer, and perhaps because it is seemingly more humane than the above-described "therapies." Still, continued medical research, coupled with increasing concern for mental patients' humanity and rights, might help standards of decency to evolve further, rendering the use of psychotropic drugs disfavored and unconstitutional.

Although the standards for determining cruel and unusual punishment are flexible, judicial decisions have created three tests to discern eighth annendment violations: (1) whether the pumishment is fundamentally unfair; (2) whether the punishment is disproportionate to the offense for which it is imposed; and (3) whether the punishment goes beyond that which is necessary to achieve its purpose. Some courts use only one of the three tests to determine whether a punishment is cruel and unusual; other courts use them collectively. ${ }^{266}$

\section{a. Fundamental Fairness}

As articulated by Chief Justice Earl Warren in Trop v. Dulles, "[t]he basic concept underlying the Eighth Amendment is nothing less than the dignity of man. While the State has the power to punish, the Amendment stands to assure that this power be exercised withm the limits of civilized standards."267 Thus, under the first test, a punishment that is "of such character or consequences as to shock the general conscience or

Patient's Right to Refuse Psychosurgery and Shock Treatment, 15 SANTA CLARA L. REv. 725, 736 (1975) (authored by Zachary E. Zwerdling).

263. Note, supra note 61, at 632-33.

264. Id. at 631-32.

265. Miron, supra note 84, at 348; see also Miron, A Final Rejoinder, in 2 Control of Human BEHAVIOR, supra note 84 , at 357 .

266. Note, Recent Applications of the Ban on Cruel and Unusual Punishments: Judicially Enforced Reform of Nonfederal Penal Institutions, 23 HASTINGs L.J. 1111, 1125 (1972) (authored by Gary Wood).

267. Trop, 356 U.S. at 100 (plurality opinion). 
to be intolerable to fundamental fairness" is unconstitutional. ${ }^{268}$

"Fundamental fairness" is the test most often einployed in eighth amendinent cases, most likely because it is derived from the earliest decisions concerning the scope of the amendment. ${ }^{269}$ It was refined in Furman v. Georgia, ${ }^{270}$ in which the Supreene Court ruled that imposition of the death penalty under certain circumstances would constitute cruel and unusual punishment. Justice Brennan in his famous and oft-cited Furman concurrence declared that "a punishment must not be so severe as to be degradmg to the dignity of hunian beings,"271 reasoning that severe inental pam, as well as physical suffering, could trigger an eighth amendment violation. ${ }^{272}$

So too inay the extreine inental and physical intrusiveness of psychotropic drugs violate civilized standards of decency. Forced niedication, in oral or intramuscular form, constitutes a serious intrusion upon the body of the subject. In addition, few punishments intrude more upon the subject's mind. ${ }^{273}$ The subject is generally not able to resist the mood swings caused by the inedication. And, significantly, the effects can go beyond even those intended by the official adninistering the drugs. One medical expert's characterization of apoinorphine, which causes severe vomiting spells, apphes equally to nrany psychotropic drugs: "[Apomorphime's] use is really punishment worse than a controlled beating since the one administering the drug can't control it after it is administered."274

The negative effects of psychotropic medications erode the basic core of human dignity of a inentally ill prisoner. The nausea, parkinsonisn1, akathisia, dystonia, and dyskinesia associated with the use of these drugs attack the fundamental well-being of the recipient. Such degradation robs the subject of her physical integrity. Arguing that electroshock therapy and psychosurgery are prohibited by the Furman test, one commentator pointedly declared, "Certainly turning one into a human vegetable demeans one's dignity."275 Prisoners have good cause to object to

268. Lee v. Tahash, 352 F.2d 970, 972 (8th Cir. 1965).

269. See Note, supra note 266 , at 1125 .

270. 408 U.S. 238, $239-40$ (1972) (per curiam).

271. Id. at 271 (Brennan, J., concurring).

272. Id. In this context, one scholar's remarks are particularly appropriate: "Perhaps the most ubiquitous form of violent punishment-as-therapy im prisons is accomplished with tranquilizing drugs. To immobilize a person against his will with drugs is violence for the same reasons that chaiming a person to the wall with shackles is violence." Opton, supra note 217 , at 639.

273. For a discussion of the imtrusive nature of these drugs on mental capabilities and thought processes, and the first amendment implications of this intrusiveness, see supra text accompanying notes 201-08.

274. Knecht v. Gillman, 488 F.2d 1136, 1138 (8th Cir. 1973) (citing testimony of Dr. Steven Fox, University of Iowa).

275. Wade, The Right to Refuse Treatment: Mental Patients and the Law, 1976 DET. C.L. REV. $53,66$. 
forced medication on the grounds that it violates the fundamental fairness test of the eighth amendment, for forced drugging without question degrades basic human dignity.

Justice Brennan's Furman concurrence states an additional standard by which to determine whether a punishment respects human dignity or violates fundamental fairness: "[T] $]$ he State must not arbitrarily inflict a severe punishment." 276 Using drugs in prisons to control inmates and keep them quiet and docile, a common practice, ${ }^{277}$ is a decision completely withm the discretion of a prison administrator. This use of drugs for administrative convenience can easily lead to the arbitrary administration of psychotropics, a clear violation of Justice Brennan's charge under the eighth amendment.

\section{b. Disproportionality and Excessiveness}

The second standard generally relates to the severity of the offense for which a prisoner is punished: A punishment is cruel and nnusual if it is greatly disproportionate to the offense for which it is imposed. ${ }^{278}$ The court will weigh "the social and administrative harm caused by the prisoner's conduct [against] the enotional and physical damage caused the inniate by the particular method of punishnient."279

The painful, frightening, and often irreversible effects of the psychotropic drugs, which mentally ill prisoners must endure, are almost by definition greatly disproportionate to the relative harmfulness of whatever behavior they are intended to address in prison medical facilities. Certanily any administration of such horrific medication must be disproportionate in the case of a prisoner not dangerous to himself or others.

Under the third, final, and perhaps least frequently used ${ }^{280}$ eighth aniendnient test, a punishnient that goes beyond its legitimate punitive ain1 will be cruel and unusual. ${ }^{281}$ As stated by Justice Brennan in Furman:

A punishment is excessive if it is unnecessary: The infliction of a severe punishment by the State cannot comport with human dignity where it is nothing more than the pointless infliction of suffering. If there is a significantly less severe punishment adequate to achieve the purposes for which the punishment is inflicted, the punishment inflicted is unneces-

276. Furman, 408 U.S. at 274 (Brennan, J., concurring) (emphasis added).

277. Opton, supra note 217, at 639-43; see also supra text accompanyimg notes 59-85.

278. See Robinson v. California, 370 U.S. 660, 667 (1962); Weems v. Umited States, 217 U.S. 349, 381-82 (1910).

279. Note, supra note 266 , at 1126-27.

280. Id. at 1127 .

281. See, e.g., Weems, 217 U.S. at 368. 
sary and therefore excessive. ${ }^{282}$

In many imstances, involuntary drug treatment may fail to satisfy this standard and will thus violate the eighth amendment. Many patients are treated with medication because it is less expensive, and takes much less staff assistance, ${ }^{283}$ than would psychotherapy. Indeed, psychiatric decisions in prisons are necessarily made on the basis of information provided by a prison staff that is often woefully madequate. ${ }^{284}$ Psychotherapy, however, is a much less dangerous and less intrusive procedure than psychotropic drug therapy and could, at least in some cases, achieve the purported rehabilitative purposes of drug therapy.

In many instances, then, the use of medication without the informed consent of the mentally ill but competent prisoner may fail to conform to any one of these standards. A prisoner may thus challenge forced psychotropic drug treatment under the eighth amendment.

\section{Future Developments}

Courts have recently been willing to prohibit the use of certain involuntary drug treatments under the eighth amendment. Perhaps the best known cases in this area are Knecht v. Gillman ${ }^{285}$ and Mackey v. Procunier. ${ }^{286}$ Several courts have specifically addressed eighth amendment challenges to medication. Not surprisingly, many of the successful claims have arisen in a penal context.

In Knecht, prison officials administered the vomit-inducing drug apomorphine as part of an involuntary aversive conditioning program. Injections followed everyday misbehaviors, such as failure to rise when ordered, distributing cigarettes against orders, talking, swearing, or lying. ${ }^{287}$ After injection, drugged prisoners vomited for a period lasting from fifteen to sixty minutes. Rejecting the institution's position that the program was "treatment" insulated from eighth amendment scrutiny,

282. 408 U.S. at 279 (Brennan, J., concurring) (citations omitted).

283. See, e.g., Welsch v. Likins, 373 F. Supp. 487, 503 (D. Miın. 1974), aff'd in part, vacated \& remanded in part, 550 F.2d 1122 (8th Cir. 1977) (insufficient staffing is a rationale for excessive use of tranquilizers for behavior control).

284. Milleman, supra note 126 , at 40 .

[T]rained and experienced prison administrators often exist only at the top of the "correctional iceberg." The lower echelon correctional officers responsible for policy implementation and day-to-day decision-making are almost always underpaid, understaffed, or inadequately trained. Recent decisions are replete with examples of the substantial extent to which custodial officers, sometimes in conjunction with inmates, assume and exercise significant decion-making [sic] within a prison.

Id. (citations omitted).

285. 488 F.2d 1136 (8th Cir. 1973); see also supra text accompanying notes $241-43$ (discussing Knecht).

286. 477 F.2d 877 (9th Cir. 1973); see also supra text acconipanying notes 72-73 (discussing Mackey).

287. Knecht, 488 F.2d at 1137. 
the Eighth Circuit held that the program constituted cruel and unusual punishnient, and ordered the trial court to enjoin adninistration of the drug unless patients gave written consent and were adjudged informed and competent enough to do so by a physician. ${ }^{288}$ The court also required that consent be revocable at any time, and that a doctor authorize each injection. Finally, the court required that any violation prompting the administration of the drugs be witnessed by a professional staff member. ${ }^{289}$

In Mackey, the Ninth Circuit stated that the use of anectine on fully conscious prisoners in an aversive conditioning program intplicated the cruel and unusual punishment clause. The drug was used as part of a prograin of aversion therapy. Anectine is not normally administered to conscious patients because of its "frightening effects."290 Plaintiffs insisted that they were unable to breathe as a result of the drug. ${ }^{291}$ The court held that if plaintiffs proved their allegations, serious constitutional questions would be raised-including possible violation of the right to privacy-caused by impermissible interference with mental processes and the use of cruel and unusual punishment. ${ }^{292}$

A class action on behalf of boys institutionalized in a state training school successfully challenged the institution's practice of punitively administering tranquilizers in Pena v. New York State Division for Youth. ${ }^{293}$ The institution's staff used Thorazine and other tranquilizers to control the "excited behavior" of the boys. Boys were also kept in isolation for over twenty-four hours (without the permission of appropriate authorities), bound with physical restraints connecting their liands and feet behind their backs, and left lying on their stomachs on the floor. ${ }^{294}$ These practices violated New York regulations, yet the district court found "[m]ost shocking" the violations of the regulations pertaining to drug admimistration. ${ }^{295}$ Holding that the particular conditions under which it was adninistered violated the eighth amendment, the court enjoined the use of Thorazine as a punitive device at the imstitution. The court did, however, authorize the drug's use as part of an ongoing treatment prograin supervised by a doctor. ${ }^{296}$ The court also found the boys should have the option of taking the drug orally, which lessens its

288. Id. at $1140-41$.

289. Id.

290. Mackey, 477 F.2d at 878 .

291. Id. at 877.

292. Id. at 878. An eighth amendment rationale was also employed by the Seventh Circuit in Nelson v. Heyne, 491 F.2d 352, 355-57 (7th Cir.), cert. denied, 417 U.S. 976 (1974). See supra text accompanying notes 248-51 (discussing Nelson).

293. 419 F. Supp. 203 (S.D.N.Y. 1976).

294. Id. at 210-11.

295. Id. at 210 .

296. Id. at 211 . 
psychological and physical dangers. ${ }^{297}$

In Souder v. McGuire, ${ }^{298}$ the district court ruled that involuntary administration of psychotropic drugs to an inmate at a state hospital for the criminally insane gave rise to an action under the federal Civil Rights Act. The court declared that "involuntary administration of drugs which have a painful or frightening effect can amount to cruel and unusual punishment, in violation of the Eighth Amendment."299

Finally, as noted above, Nelson v. Heyne ${ }^{300}$ concerned the use of Thorazine and Sparine to control excited behavior of juveniles at a correctional institution. The court held that the intramuscular administration of the drugs to juveniles by correctional staff without first attempting less drastic ineans of control, and without adequate inedical guidance or prescription, violated the eighth ainendment. ${ }^{301}$

In suin, the eighth amendment's prohibition against cruel and unusual punishment has been held to provide a ininimum safeguard against forced inedication where a patient is competent and poses no emergency threat to herself or to others. Despite the Supreme Court's refusal to expand prisoners' due process rights in Harper, the eighth amendment's prohibition against cruel and unusual punishment should provide a safeguard agamst the forced use of such medication. Psychotropics can cause painful and dangerous side effects; thus, in essence, their use without informed consent constitutes punishinent. The negative consequences and the highly intrusive nature of the drugs are so intolerable that they meet the standards enunierated by the courts to sustain a charge of cruel and unusual punishment.

297. Id.

298. 423 F. Supp. 830 (M.D. Pa. 1976).

299. Id. at 832 .

300. 491 F.2d 352 (7th Cir.), cert. denied, 417 U.S. 976 (1974); see supra text accompanying notes 248-51, 291-92 (discussing Nelson).

301. In addition to its findings on medication, the Nelson court held certain corporal punishment to be in violation of the eighth amendment. In the portion of its opinion discussing corporal punishment, the court made some observations that are also applicable to drug trcatment. It noted that corporal beatings are "easily subject to abuse in the hands of the sadistic and unscrupulous, and control of the punishment is inadequate." Nelson, 491 F.2d at 356. The identical observation may be made about the forced administration of psychotropic drugs to mentally ill prisoners, in a context that rarely comes under public scrutiny, and in which there are few prisoner advocates.

Admittedly, the circumstances in Nelson involved improper administration, whereas the thesis of this Comment also encompasses drugs administered according to medical standards. Still, it remains significant that the Nelson court recognized that drug administration is punishment.

Finally, at least one ease explicitly found that forced administration of psychotropics in a nonpenal hospital setting may constitute cruel and unusual punishment. See Welsch v. Likins, 373 F. Supp. 487, 503 (D. Minn. 1974), aff'd in part, vacated \& remanded in part, 550 F.2d 1122 (8th Cir. 1977). 


\section{Conclusion: The Prisoner's Right to Refuse PSYCHOTROPIC MEDICATION}

This Comment has described the various psychotropic drugs and considered whether prisoners have the right to refuse their use. The Supreme Court in Washington v. Harper determined that the state of Washington's pohicies and procedures were sufficient to guarantee adequate due process and the inmate did not have the right to refuse the forcible administration of the drugs. Harper, however, recognizes the important right of prisoners to refuse noncurative treatinent with psychotropic drugs and thus avoid the severe, potentially permanent side effects. The case, therefore, does not rimg the death knell for a constitutional right to refuse. A valid basis for challenge still lies in the case-bycase application of procedural due process analysis. Moreover, the Harper decision failed to address other key issues, mcluding the source of the right to refuse and the important substantive protections for the inmate. Harper does not address the inmate's right to refuse based on the first amendment, the right to privacy, or the eighth amendment protections against cruel and unusual punishinent.

This Comment has demonstrated that these constitutional protections require the courts to honor the inmates' refusal except where a state interest in protecting the inmate or others from harm exists, and where no less restrictive analysis would suffice. The courts, of course, should be particularly careful to avoid equating refusal to accept treatment with incompetence. A respect for the right of the individual to make judgments not in his "best" interest must be inaintamed. If the correctness of therapy and the irrationality of refusal become the touchstone of the incompetency determination, an empty right is created. A prisoner would then be permitted to refuse only those therapies which he is willing to accept: This is certainly not the intent of recognizing a right to refuse treatment. The courts ought to examme the validity of the psychiatric diagnosis upon which the need for treatment is based, the capacity of the individual to inake a responsible treatment decision, and the availability of less intrusive methods of treatment.

Such an approach obviates the need for a substituted judgnient of an incompetent prisoner's desires, and shifts the focus of the inquiry to whether the state has shown the necessity for using psychotropic drugs. The goals of allowing the individual, im all but the inost extreme cases, to inake difficult choices regarding potentially harmful treatment, would thus be preserved. 
